\title{
O selvagem na "Gesta Dei": história e al- teridade no pensamento medieval
}

\author{
Klaas Woortmann \\ Professor de Ciências Sociais da U N B
}

\section{RESUM O}

0 propósito do artigo é examinar a noção de selvagem no pensamento medieval e sua relação com o sentido de história. Resultado da combinação deidéias herdadas da Grécia antiga, da tradição judaica e de concepções européias précristãs integradas a uma concepção providencialista da história, a noção de selvagem surge como mediadora das relações de alteridade no tempo e no espaço. Concomitantemente, revela a dificuldade de lidar com a diferença.

Palavras-chave: Selvagem; Alteridade; Teologia medieval

\begin{abstract}
The article examines the idea of Wild $M$ an in medieval thought. Resulting from a combination of ancient Greek conceptions, judaic ideas and pre christian notions, integrated into the medieval theological conception of history, the notion of Wild M an serves as a mean for the construction of otherness. At the same time it reveals the difficulties of dealing with cultural differences in time and space.
\end{abstract}

Keywords: Wild M an; Otherness;

Medieval theology.

O chamado "selvagem" foi sempre um brinquedo para o homem civilizado ... fonte de emoções fortes na teoria. O selvagem foi sempre chamado para dar foros de autenticidade a essa ou aquela hipótese a priori, tornando-se, conforme o caso, cruel ou nobre, lascivo ou casto, canibalesco ou humanitário - em suma, o que melhor conviesse ao observador ou à teoria.

B. Malinowski ${ }^{1}$

A partir das navegações empreendidas pelos portugueses e da chegada de Colombo à América, uma nova humanidade ingressou no horizonte mental europeu. Perante ela, a Europa foi gradativamente obrigada a se repensar. Ao mesmo tempo, os europeus tiveram que pensar o ameríndio, assim como 
os vários outros povos com que foram se defrontando pelo mundo afora. Nesse processo surgiu um novo "selvagem", transposição para o Novo M undo de construções de alteridade já existentes no imaginário europeu, e em boa medida herdadas do pensamento antigo e do medieval. É sobre este último que lanço aqui meu olhar.

Em trabalho anterior ${ }^{2}$ procurei mostrar que o pensamento grego, com poucas exceções, tais como aquela representada por Heródoto, em suas considerações sobre os citas, ${ }^{3}$ não revel ou sensibilidade para a compreensão do Outro. 0 pensamento medieval, em parte herdeiro de idéias gregas, tampouco favorecia o estudo da alteridade etambém nele o O utro "incompreensível" podia ser pensado como selvagem. A tradição hebraica incorporada ao cristianismo, por sua vez, podia levar à qualificação do selvagem como satânico.

A dificuldade em lidar com a alteridade fazia com que não fosse incomum a atitude segundo a qual tudo que não fosse cristão era anticristão. Em boa medida, o único interesse por outras religiões estava na sua supressão. Existiam relatos etnográficos, mas a literatura relativa a outros lugares que não a Europa tendia a girar em torno de monstros e maravilhas herdados da Antigüidade, e a certas categorias, como deserto e nomadismo, definidoras de um estado/estágio selvagem. Aquela literatura e essas categorias vieram a se combinar com idéias centrais à teologia medieval e com uma particular concepção histórica do homem.

O monoteísmo e a Criação única levavam à idéi a de uma humanidade fragmentada no tempo mas que poderia ser reunificada. N essa humanidade poderia ser incluído, ainda que de maneira extremamente ambígua, o selvagem, na medida em que el e teria sido produzido pela Queda. No cristianismo agostiniano a idéia de uma totalidade da Criação disposta na Grande Cadeia do Ser não era incompatível com uma eventual unificação da humanidade no fim dos tempos. No tempo colocava-se a diferenciação; fora do tempo (fim dos tempos) a reunificação do que fora separado pela Queda.

No cristianismo medieval, além de uma divisão hierárquica do cosmos em geral e da humanidade, se estabelecia também uma divisão entre salvos pela graça e condenados. Contudo, o D eus cristão, mais tolerante que o dos hebreus, poderia reunificar os homens, na medida em que estes se reunificassem com D eus. Em certas representações os condenados podiam ser assimilados a selvagens.

Na concepção hebraica, como mostra White, ${ }^{4}$ o selvagem tinha um estatuto ontológico: a encarnação da mal dição; seus atributos mentais eram os da loucura e/ou depravação. Os gregos também podiam perceber os selva- 
gens como loucos, mas a atitude moral para com eles era diferente: enquanto o pensamento hebraico assimilava estados físicos a estados morais, reduzindo atributos exteriores à manifestação de uma condição espiritual, os gregos tendiam a materializar estágios espirituais.

Para os hebreus a concepção do selvagem era função da concepção de um Deus único que havia povoado o mundo com espécies em si mesmas perfeitas, com o homem, perfeito em sua espécie, no centro moral desse mundo. Com o pecado, contudo, sobrevei o a Queda que, com o cristianismo, foi interpretada como trazendo a mácula que impede os homens de viverem "cristãmente" sem a ajuda da graça.

Para os hebreus a Q ueda não tornou todos os homens selvagens, nem mesmo todos os gentios. De fato, os gentios podiam fornecer o paradigma do homem natural, enquanto os hebreus, povo do pacto com Deus, fornecia o paradigma da humanidade redimível. Ao lado do homem natural e do homem moral havia, no entanto, uma terceira humanidade, a do homem selvagem, de quem Deus retirou a benção de maneira absoluta e que, em decorrência da retirada da benção, teria degenerado para um estado inferior ao próprio estado do homem natural.

$\mathrm{N}$ a vertente grega do pensamento medieval o selvagem, na medida em que era apenas silvaticus, podia ser equiparado a um animal, a um ser da natureza. Ou a um híbrido como o centauro, ambíguo, por certo, mas não necessariamente mau. Porém, como mostra Bartra, ${ }^{5}$ as guerras com centauros eram metáforas das guerras com bárbaros.

A tradição judaica, todavia, ao transmitir a idéia de maldição, criou ainda uma outra imagem pela qual o homem selvagem não se equiparava ao animal, pois a natureza animal não era em si selvagem, mas apenas não-humana. $O$ estado do homem selvagem é subumano; é uma condição moral, um estado de maldição.

Herdando tais concepções e combinando-as de variadas formas com idéias pré-cristãs européias, o cristianismo medieval constrói a diferença entre os homens como expressão da corrupção da espécie, pois haveria graus distintos de aproximação com a forma perfeita de humanidade na GrandeCadeia do Ser. 0 mais afastado daquela forma era o selvagem.

A divisão da humanidade era dada, portanto, por razões transcendentais e se ela se expressava no espaço - com o selvagem localizado no deserto, na floresta ou nos confins do mundo - , ela se constituía fundamentalmente no tempo, um tempo escatológico que mediava entre a Queda e o Juízo Final. 


\section{E como era pensado o tempo? De acordo com Gusdorf,}

A Idade M édia viveu numa espécie de presente eterno: o esquema litúrgico da história sagrada, indefinidamente repetido, fornecia o quadro da vida social e da existência pessoal ... Jamais a cidade dos homens se quis tão exatamente idêntica à Cidade de Deus, que lhe serve de protótipo escatológico, bloqueando em si o passado, o presente e o futuro ${ }^{6}$

A afirmação de Gusdorf, ainda que correta em vários sentidos, deixa a impressão de que no M edievo inexistia uma concepção de história. M as essa seria uma conclusão equivocada. 0 pensamento medieval era radicalmente cristão e o quadro desse pensamento era dado por uma teologia que implicava uma percepção particular do tempo. Justamente por ser cristão, era um pensamento eminentemente histórico, ainda que teocêntrico. Como foi visto, a fragmentação da humanidade se deu no tempo.

Collingwood ${ }^{7}$ mostra que o cristianismo trouxe consigo certas idéias centrais que iriam moldar o pensamento histórico; entre elas, a idéia de uma Criação localizada num momento preciso. Ao contrário do pensamento greco-romano, que não concebia a possi bilidade de criação de algo a partir do nada, essa idéia trouxe consigo uma específica noção de causa, de devir e de progresso.

Porém, o cristianismo medieval retomou, de certa forma, um tema grego. D ada a Queda, o homem sofreu de uma cegueira inerente à condição humana. Para os gregos, o homem podia mudar a história, mas o curso desta permanecia ininteligível, visto que o mutável escapava às possibilidades da epistéme; só as leis imutáveis poderiam corresponder ao conhecimento pleno. Para santo Agostinho, o homem faz o que pretende fazer, em vez de seguir o caminho justo para a ação. É esse desejo indomado que conduz ao pecado original. M as para o pensamento medieval, o homem era também o instrumento da Providência e apenas esta dava inteligi bilidade aos atos humanos. As leis imutáveis foram substituídas pelo Deus imóvel (porquanto perfeito).

Por isso, as real izações do homem, apenas aparentemente resultantes de seu intelecto, são na realidade dirigidas por uma sabedoria que lhe é externa, a sabedoria divina. Suas realizações, seus progressos são realizações da Divina Providência. Assim, se Roma conquistou o mundo, isto não resultou de um plano concebido pelos homens, mas por Deus. 
Pela via da doutrina cristã, o homem é apenas um meio para a consecução dos fins estabelecidos por Deus, a quem cabe

determinar, de tempos a tempos, os objetos que os seres humanos desejam. Todo agente humano sabe o que quer e procura atingir o seu objetivo, mas não sabe por que razão o quer: a razão por que o quer está no fato de Deus o ter levado a querê-lo, a fim defazer avançar o processo de concretização deSeus desígnios. Em certo sentido, o homem éo único agente da história, porquetudo o queacontece na história acontece por sua vontade; noutro sentido, Deus é o único agente, porque é apenas através da atuação da providência divina que o exercício da vontade humana, num dado momento, conduz a este resultado e não a um resultado diferente. ${ }^{8}$

Se o cristianismo manteve, em vários contextos de pensamento, a noção grega de substância (como na explicação da Eucaristia pela via de uma ciência aristotélica) , a doutrina da Criação negava a doutrina metafísica da substância em outros contextos. Nada é eterno, exceto Deus; a própria alma individual é desprovida de existência passada ab aeterno.

Se nada é eterno, tampouco o são os povos ou nações criados por Deus; por isso mesmo, podem ser por Ele recriados ou redirecionados. Pela graça divina, os povos podem evoluir ou deixar de existir. Cria-se, então, numa linguagem teológica, uma noção de transitoriedade finalista: Roma não é eterna, mas uma entidade transitória que surgiu num momento da história para realizar certas funções; realizadas estas, Roma desaparece, tendo cumprido o seu papel. N ão deixa de haver um certo "utilitarismo transcendental" nessa concepção.

Para Collingwood, o pensamento cristão revoluciona a história, na medida em que engendra a idéia de que o processo histórico cria seus veículos: Roma não era pressuposto mas produto do processo histórico. M as é preciso não esquecer o essencial do pensamento medieval: a história humana não é uma história feita pelo homem.

Vale salientar que os europeus medievais, tanto quanto os romanos com relação aos gregos, também não percebiam diferenças significativas entre eles próprios e os antigos, muito embora a famosa "querela" antigos versus modernos, característica do Renascimento, já se tivesse iniciado no M edievo; 0 que se percebia era uma continuidade, mesmo porque o latim era a língua comum escrita. Apenas al gumas diferenças pontuais eram reconhecidas. Assim, Alexandre, o Grande, era retratado como um monarca feudal, e os heróis ro- 
manos, em trajes medievais. SeH eródoto havia helenizado as divindades egípcias, o pensamento medieval "europeizou", nos termos da época, os antigos gregos, o que sugere uma falta de "distância de perspectiva", ${ }_{10}$ impedindo a percepção das civilizações antigas como totalidades coerentes. Tal atitude bloqueava, evidentemente, a apreciação da alteridade.

No pensamento medieval, como foi visto, a humanidade era diferenciada pela via da graça. A fusão das tradições grega e hebraica fez surgir até mesmo uma subumanidade. Porém, para o cristianismo, todos os homens são iguais, inexistindo um povo eleito; nenhuma comunidade tem um destino mais importante que qualquer outra. Este ponto de vista seria retomado, séculos mais tarde, em oposição ao universalismo iluminista, por Herder e pelos românticos inspirados no pietismo luterano, em outra convergência entre religião e história. ${ }^{11} \mathrm{O}$ contexto teocêntrico medieval, contudo, não permitiu que se apreendesse a alteridade ou a particularidade, no tempo ou no espaço, em seus próprios termos. Pelo contrário, tal concepção leva à idéia de uma história do mundo, pois o processo histórico é sempre igual em todos os lugares.

Era preciso, então, estender a manifestação de Deus para toda a humanidade. Para isso era preciso construir um tempo unificado, uma cronologia única, o que foi feito tendo as Escrituras como referência central.

As histórias universais do século III são, portanto, cronologias sincronizadas. Elas dão testemunho de uma comovente necessidade de sincronizar cronologias fragmentárias, a fim de estabelecer as concordâncias entre cada uma delas e a história santa narrada pela Bíblia. Ao percorrer estes quadros de concordância ... sentimos a preocupação de fazer viver o mundo inteiro ao ritmo da revelação divina: uma espécie de apostolado regressivo que evangelize a história para trás. ${ }^{12}$

A construção de uma humanidade única foi uma exigência fundamental do cristianismo para que, desde a patrística, se engendrasse a concepção providencialista da história: unidade no espaço e unidade no tempo, sob a égide da Vontade Divina, compõem o universalismo necessário ao cristianismo. Segundo tal concepção não existiriam eventos com significado em si mesmos; apenas sinais místicos de um governo divino. Por isso, a história se torna também milenarista ou apocalíptica.

A tendência ao universalismo transcendental fez que a história medieval cuidasse menos deste ou daquele país que de relatar a gesta D ei. Se o processo histórico, isto é, o caminho trilhado pela humanidade tinha uma lógica, esta era dada pela vontade divina e o curso dos acontecimentos era o critério para 
avaliar os indivíduos que dela participavam. Se os desígnios divinos eram inescrutáveis, o dever do indivíduo era o de servir voluntariamente como instrumento de suas finalidades.

A rigor, o indivíduo autônomo, o indivíduo como idéia-valor, ${ }_{13}^{13}$ não existia. Numa relação transcendental entre o todo e a parte, o indivíduo que se opusesse a tais desígnios apenas condenava a si próprio. M ais que indivíduos, tinham-se "personas" num drama divino. Se o indivíduo era desprovido de significado, não menos o era o evento particular.

M as um breve parêntese deve ser aberto com referência a Guilherme de Ockham, precursor da ideologia individualista moderna. No contexto da discussão franciscana sobre a propriedade e sobre o poder do papa, Ockham se contrapôs à maioria dos teólogos do século XIII, cujos pontos de vista se fundavam em Aristóteles. Como ressaltam Souza \& De Boni,

O ckham ... percebe que é necessário salvar a liberdade absoluta de Deus, cuja vontade se determina apenas por si mesma, e com isto abre espaço para o conhecimento da realidade humana como realidade contingente. [ Para os teólogos do século XIII ] após explicar-se a abstração, perguntava-se: como é possível o conhecimento das coisas em sua singularidade? Ockham inverte a questão ... o que temos são coisas individuais, numericamente diferenciadas entre si: que valor tem então nosso conhecimento universal? ${ }^{14}$

O mundo éum mundo deindivíduos. Existem apenas as substâncias primeiras. Quanto às substâncias segundas, vale seu exemplo relativo a ordens religiosas: não existe uma ordem dos beneditinos (ou franciscanos, ou outra qualquer); existem apenas frades individuais. Seu pensamento se afasta, pois, da concepção hierárquica medieval, em que o todo predomina sobre a singularidade. ${ }^{15}$ Para ele, como também aponta Dumont (1985), o que existe é

Um mundo de indivíduos iguais entre si e sem intermediários ... um mundo que encontra sua própria explicação dentro de si mesmo ... um mundo que se organiza a partir de seus membros constituintes. Uma tal compreensão conserva até hoje resíduos revolucionários - imagine-se então o que ela significou quando aplicada à Igreja dos papas de Avinhão. ${ }^{16}$

Para O ckham as leis civis e as canônicas têm igual valor, e não se deveria subordinar uma à outra. Por isso, os poderes papais derivados de concessões mundanas deveriam ser objeto de análise dos juristas, e não apenas dos teó- 
logos. Assim, Ockham refuta o princípio de plenitudo potestatis, já antevendo uma separação entre I greja e Estado. Aquele princípio seria prejudicial tanto para os cristãos como para os seguidores de outras religiões, que não teriam 0 direito à herança, assim como não o teriam tampouco as crianças não batizadas, ainda que de famílias cristãs. A atitude de 0 ckham com relação aos pagãos, isto é, aqueles fora da trilha providencial, era de considerável tolerância. Para ele também os pagãos teriam o direito de propriedade, visto que

No estado de inocência original os homens possuíram e exerceram um direito comum sobre os bens terrenos. Após a queda de nossos primeiros pais foi introduzido 0 direito de propriedade privada por eles mesmos, graças à concessão de tal capacidade que Deus Ihes proporcionou. Ele também Ihes concedeu o poder para estabelecerem governantes por si próprios, a fim de regular de maneira melhor a convivência político-social e econômica, em face das ambições provocadas pela natureza decaída. ${ }^{17}$

Ockham, portanto, ao privilegiar o indivíduo postulava também um plano de explicação mundano, humano. De uma maneira geral, porém, desde a Cidade de D eus o sentido da história é teológico; o que se impunha aos homens era descobrir tal sentido, expor o plano divino, na medida das possibilidades do conhecimento humano. Parte substancial desse esforço se manifesta no estabel ecimento de períodos históricos. Foi a percepção escatológica do tempo, comum também ao islamismo, que conduziu à periodização religiosa da história. Santo A gostinho elabora o que é provavelmente a primeira filosofia da história escrita do O cidente cristão. É o primeiro passo no sentido da compreensão da evolução da humanidade como um todo, o grande projeto da I dade M édia. Santo Agostinho foi a inspiração de vários cronólogos que dividiram a história universal em seis idades, correspondentes aos dias da Criação. Ele previra também uma sétima idade, o final dos tempos, mas esse final não era precisamente previsível.

Em 725 o Venerável Beda publicou seu De temporum ratione onde se contam os anos a partir da Encarnação. Independentemente de Beda, até hoje, no mundo cristão, a grande divisão do tempo é aquela que o separa em antes e depois de Cristo.

O esforço de periodização era parte da grande ênfase posta na “história universal" como teoria/teologia da humanidade, destinada a determinar o fim do mundo. Se o estabelecimento de períodos já representa um pensamento histórico, ele implicava, contudo, uma temporalidade mergulhada numa percepção religiosa do mundo. 0 livro de Beda é, para W hitrow, ${ }^{18}$ o locus classi- 
cus do conceito de "idades do homem": a vida humana não transcorre num tempo contínuo, quantitativo, mas é pontuada por descontinuidades, de uma "idade" para outra num tempo qualitativo, litúrgico.

Se o modelo das seis idades evocava a Criação, outro modelo, o das quatro idades do homem associava-se às quatro estações do ano, aos quatro pontos cardeais e aos quatro elementos da matéria segundo Aristóteles, assim como aos humores de H ipócrates. Com relação a esse modelo poder-se-ia dizer que o tempo medieval era um tempo ritual-cósmico. ${ }^{19}$

Quatro idades, ou seis ou sete, de base teológica e/ou astrológica, marcavam um tempo cíclico ou litúrgico. Essas idades eram tanto as do homem indivíduo como do homem espécie. Se havia as quatro idades do homem, havia também os Quatro Impérios da história ou, alternativamente, os Três Reinos (do Pai, do Filho e do Espírito Santo).

Porém, o tempo histórico incluía o futuro. A referência ao futuro partia da Revelação, não apenas do que Deus tinha feito no passado, mas também do que faria no futuro. A historiografia medieval era, pois, escatológica: a Revelação nos mostra toda a história do mundo, desde sua criação até seu final. A história, então, se realizada no tempo, implicava uma visão intemporal de Deus, governante dessa história.

Sendo escatológica, era também uma concepção de história teocêntrica, e esse teocentrismo tem o conteúdo de um transcendentalismo que reevoca 0 substancialismo antigo e as leis universais imutáveis. Poder-se-ia dizer que as leis científicas gregas foram substituídas por uma "mão invisível" divina. Assim, os historiadores medievais buscavam a essência da história fora da história, no plano divino. Era como que uma crônica da condição humana. Aos olhos modernos aquela historiografia era, evidentemente, insatisfatória. M as, se a examinarmos em seus próprios termos e com certo relativismo comparativo com os nossos próprios tempos, o estranhamento ganha um certo toque de familiarização:

talvez não estejamos inteiramente relutantes em relação a teorias que ensinam que as transformações históricas em larga escala são devidas a certa forma de dialética, que atua objetivamente e modela o processo histórico através de uma necessidade independente da vontade humana. Isto leva-nos a um contato bastante estreito com os historiadores medievais. ${ }^{20}$

Em tempos mais modernos outra "mão invisível", mas teoricamente cognoscível e, na aparência, laicizada, passou a operar sobre os destinos dos ho- 
mens. E outras "forças", dialéticas ou não, se constituíram no motor de uma história igualmente "necessária".

Surgiu então uma temporalidade em que o sentimento de duração era central, como em santo Agostinho, cujo projeto incluía o futuro da humanidade em conjunto. "D e santo Agostinho a Bossuet, a distância não é grande". ${ }^{21}$

A Cidade de D eus é como que uma mediação entre uma concepção antiga, romana, voltada para o passado, e outra nova, providencialista, voltada para o futuro e para a revelação divina. Escrevendo no contexto do saque de Roma por Alarico, num momento em que se discutia a sério a duração de Roma, para santo Agostinho era fundamental combater a idéia de que o fim de Roma seria também o fim do cristianismo, previsto por alguns para o ano 367. As especulações cronológicas de santo Agostinho se faziam num tempo que chegaria à catástrofe final. No entanto, se sua história era escatológica, havia uma diferença entre a sua concepção de tempo e aquela da época apostólica: o fim do mundo (e da história, portanto) não era iminente..22

A concepção das seis idades teria imprimido nos historiadores medievais "uma visão melancólica de seu tempo". ${ }^{23}$ M as 0 ano 1000 chegou e passou, o mundo não acabou e os historiadores puderam retomar seu trabal ho.

O milenarismo, porém, não desapareceu. Durante o medievo prosseguiu de forma variada conjugando, por exemplo, o simbolismo do sétimo dia do sabá (repouso) com a simbologia da sétima idade (fim dos tempos) . 0 principal representante do milenarismo foi Joaquim de Fiore, no final do século XII, bastante influenciado pela escatologia islâmica.

A partir de suas reflexões sobre a relação entre o mistério da Trindade e o processo temporal, postulou três idades: a de Deus (Antigo Testamento), idade do medo; a de Cristo (Novo Testamento), idade da fé; a do Espírito Santo (Sempiterno Evangel ho), idade do amor e da liberdade. M as havia em sua concepção uma diferença importante: ao contrário de santo Agostinho, a última idade estava dentro da história e não fora dela, fora dos tempos; neste mundo enão no outro mundo.

O joaquinismo implicava, então, uma concepção de história mais dinâmica. Ainda que milenarista e, por certo, mística, nela o mundo seria transformado pelo próprio homem. Seu milenarismo influenciou bastante a heresia pré-Reforma de Huss, o pensamento social de M üntzer e até mesmo os nossos dias:

O que caracteriza a tradição revolucionária cristã, de Joaquim de Fiorea John Huss, de Thomas M üntzer às teologias políticas de nossos dias, é que o Reino de 
Deus não é pensado como um outro mundo em espaço e tempo, mas como um mundo diferente, modificado pel os próprios esforços do homem ... Isto significa que éna história humana que todas as contendas são decididas ${ }^{24}$

Já se apresentava, pois, uma certa concepção antropocêntrica da história, mas ela só seria desenvolvida a partir do Renascimento.

Havia também uma outra temporalidade, aquela das crônicas, introduzida na Inglaterra, por exemplo, pelo Venerável Beda; se ele havia escrito Detemporum ratione, escreveu também uma História Edesiástica da Nação Inglesa.

As crônicas, contudo, eram tão imbricadas na teologia quanto as periodizações escatológicas, fazendo que todo o gênero histórico na I dade M édia se confundisse com uma "teologia aplicada", no dizer de Ariès (1989). As crônicas eram escritas com finalidades edificantes e a própria apresentação dos personagens segue uma ti pologia de exemplaridade, para maior glória de Deus.

No século XIII constituiu-se uma história política, cujo centro é, principalmente na França, o rei, personagem sacralizado pela liturgia e ponto focal da monarquia centralizada. Contudo, não foi uma historiografia libertada do modelo teológico. Pelo contrário, houve como que uma transposição da crônica dos santos para a crônica dos reis, seguindo o modelo da gesta Dei. 0 abade Suger produziu a primeira história da França. Se a história santa abriu lugar para a história dos santos e também para a história dos reis, esta última, como observa Gusdorf (1967), permaneceu subordinada às duas primeiras. Os Gesta Dagoberti tratam menos do rei que do fundador da abadia de Saint-Denis.

Evidentemente, não se pode esquecer que os historiadores eram clérigos, como o já mencionado Suger, abade de Saint-D enis. Por isso mesmo a história é menos dos reis da França que da França cristã, investida de uma vocação providencial. Nas Grandes Crônicas da França, tanto quanto nos vitrais das catedrais se fixa a mensagem: "Se al guma outra nação faz à Santa I greja violência, da França vem a espada por que é vingada; a França é como o filho leal que socorre sua mãe em todas as dificuldades". ${ }^{25}$ Significativamente, as Grandes Crônicas foram reeditadas em 1476 como o primeiro livro impresso na França.

A iconografia das igrejas ilustra aquele espírito:

A catedral de Reims é dedicada à liturgia da sagração; sua iconografia é dividida em dois registros: um registro de Deus e um registro de César ... ficando compreendido que o exercício do poder temporal é também de natureza 
religiosa. A articulação dos dois registros mostra bem a relação entre a história santa e a história dos reis: os reis da França sucedem aos reis de Judá e tomam o seu lugar na galeria ocidental.

A cena essencial torna-se, então, a cerimônia da sagração ... a série dos reis começa com o primeiro que foi cristão e ungido ... Torna-se então menos importante remontar para além de Clóvis ... A origem é fixada na primei ra sagração ... [e] o peregrino ... reencontra nos vitrais do trifório a cerimônia tal como se repete desde Clóvis, a cada geração: o rei, com vestes estampadas de flores de lis, de espada e cetro, cercado dos pares de França. A liturgia recomeça o gesto consagrador do primeiro rei e renova a intervenção milagrosa da pomba e da santa ampola. ${ }^{26}$

Ao tema religioso, transposto para o tema nacional, acrescenta-se o tema épico, derivado da própria estrutura feudal da Europa:

A continuidade do sangue, que beneficia os vivos com as virtudes dos mortos, a exaltação da fidelidade, valor central num regime feudal fundado sobre 0 respeito aos laços estabelecidos, impõem a elaboração de uma hagiografia semiprofana que, perpetuando a memória dos feitos antigos, justifica a autoridade dos príncipes e as honras que Ihes são devidas. Aqui ainda a evocação retrospectiva é uma projeção dos valores presentes. ${ }^{27}$

Para Gusdorf, não seria possível, no M edievo, uma história objetiva que reconhecesse a autoridade do fato em si mesmo. Ao desprezo pelo evento particular se acrescentam as exigências de direito, criando um obstáculo a mais para uma historiografia crítica. Foi o caso da "doação de Constantino", forjada para legitimar a causa da monarquia pontifícia.

A inexistência de uma historiografia crítica fazia que as crônicas não passassem de repetições de outras crônicas anteriores, às quais se acrescentavam os acontecimentos posteriores a elas. Não havia nenhuma revisão crítica. Uma tal atitude obedecia ao "argumento de autoridade"; não havia por que contestar a autoridade de cronistas anteriores. O bedecia também ao princípio de que não existia conhecimento novo, apenas recapitulações. A busca do conhecimento novo ea atitude crítica eram perigosas, desde o ponto de vista da "teologia dominante". Vale lembrar que foi justamente aquele princípio que inspirou U mberto Eco em seu 0 Nome da Rosa que, como sabemos, gira em torno da proibição do acesso a certa parte da biblioteca do mosteiro. A preocupação do monge guardião da biblioteca - significativamente cego — 
consistia em impedir a leitura de Aristóteles, leitura que poderia estimular o pensamento crítico. Só com o Renascimento, quando se firma a idéia da experiência (e do experimento) iria se transformar a noção de conhecimento.

Contudo, se a história dos reis havia sido sacralizada, ela introduzira uma nova periodização do tempo. Na França, pelo menos, introduziu-se uma periodização dividida por reinados, numa construção de temporalidade que se estenderia para os tempos modernos, paral ela à temporalidade escatológica. Sacralizada ou não, a história dos reisjá introduzia um tempo particular, mesmo que apenas exemplar dos desígnios da Providência.

Se a história era em larga medida escatológica, se a concepção do tempo era, freqüentemente, mais cíclica que propriamente histórica e irreversível, a avaliação do tempo, segundo Bloch, ${ }^{28}$ era imprecisa. Antes do século XVI, era raro existir uma consciência quantitativa do tempo. Assim, por exemplo, na Chanson de Roland não há nenhuma referência ao tempo. "A qualidade essencial do mundo era sua transitoriedade vis-à-vis Deus, não a mudança visível que prosseguia incessantemente no mundo". 29

Cartas raramente eram datadas e quando o eram, usava-se a referência aos dias santos. A exceção notável foi Petrarca, obcecado com o tempo e seus efeitos sobre a mente humana.

A imprecisão na medida do tempo e, mais ainda, a fragilidade de uma concepção quantitativa do tempo, impediram a constituição de um conceito de progresso propriamente humano, muito embora progressos tecnológicos tivessem ocorrido: óculos de leitura; o arado e formas do uso da terra; a roda de fiar; os ofícios de ferreiro em geral.

A popularização do relógio mecânico iria acompanhar a transformação da concepção do mundo. Com ele, a hora de 60 minutos substituiu o dia como medida básica detempo. No entanto, a I greja, com suas prescrições e proscrições sobre o que devia ou não podia ser feito neste ou naquele dia, nesta ou naquela hora, fazia que o tempo continuasse desigual em qualidade. As horas canônicas continuavam a seguir o ciclo do dia, do nascer ao pôr do sol. É significativo que os livros de orações fossem chamados - e ainda o são "livros das horas", entendendo-se por horas não períodos de 60 minutos mas intervalos menos precisos do ciclo diário.

M as, apesar de ser o tempo impreciso, não deixava de haver uma história. 0 homem medieval vivia imerso numa história litúrgica e por isso mesmo a história é um componente central do pensamento cristão. 0 próprio providencialismo torna necessária a ligação entre o homem e a história como ingrediente da noção de progresso transcendental. Porém, Cristo é histórico: 
ele nasceu em determinado dia durante o reino de César Augusto, quando Herodes era o tetrarca da Galiléia.

O próprio sagrado, pois, cria uma consciência histórica, mas trata-se, como visto, de uma história de redenção que culminará com uma humanidade (e não um povo específico) regenerada. 0 mundo todo partilharia uma mesma história, mas para dela participar era preciso ser cristão; por isso, a evangelização dos gentios e mesmo a salvação dos selvagens era parte da gesta Dei.

Isto teve, contudo, como foi visto, conseqüências anti-históricas. Como mostra Collingwood (1994), hipostasiando o universal como um falso particular, ele não atua dentro do tempo, mas sobre ele. Como força atuante, a vontade de Deus é sempre igual no tempo e no espaço e se manifesta externamenteà vontade dos homens. A essência da história ébuscada fora da história, tanto quanto a natureza do universo é buscada fora da física.

A iconografia das igrejas é novamente significativa, pois ela:

reunia [a] vida presente à cadeia dos tempos; uma série sem interrupção remontava do último bispo ... até o primeiro homem, passando pelas escrituras da I greja e dos dois testamentos, que se viam nas paredes e nos vitrais. Porque, e esta éa lição da iconografia gótica, a história sagrada não termina em Pentecostes nem nos primeiros apóstolos, mas, prosseguindo sem interrupção desde a criação do mundo, atrela-se à história sempre aberta da I greja ... essa filiação é lembrada sem cessar ... assim como a correspondência de Cristo com o primeiro Adão, da I greja com a sinagoga ... Os vitrais ... da catedral de Reims representam os apóstolos carregando nos ombros os patriarcas, enquanto que acima ou do lado se seguem os bispos com suas igrejas, os reis com a espada e a coroa. É nas paredes das igrejas que descobrimos a natureza da piedade medieval ... [Esta] piedade é em primeiro lugar o respeito devoto a uma história. Aos mitos de estação do paganismo agrário, a devoção cristã acrescenta um sentido sagrado da história: in illo tempore. ${ }^{30}$

A catedral medieval era mais que um templo; era a idéia do mundo. Sobretudo a catedral de Chartres, o "indivíduo arquetípico" do gênero arquitetônico gótico, como afirma Gaos (1992).

Gaos nos convida para uma visita à catedral, não como turistas ou "cientistas", mas na medida do possível como fiéis medievais. E chama a atenção para uma questão "hermenêutica” fundamental:

se identificamos as figuras e cenas percebidas em estátuas e baixo-relevos, vitrais e rosetas, é porque as percebemos possuindo um saber devido a uma educação 
ou instrução cristã que nos mostra até que ponto estamos unidos à catedral de Chartres por uma continuidade sem solução: a circunstância de Chartres éhistoricamente a nossa... ${ }^{31}$

Veríamos então que toda a iconografia, desde o Portal Real até o Portal do Senhor, da fachada e dos vitrais, é um desfile que percorre a Criação, os dezesseis antepassados de Cristo, os Apóstolos etc. ${ }^{32}$

A iconografia é uma sistematização histórica, desde a Criação, passando pelo Antigo Testamento aos profetas, e com Cristo ligando o Antigo ao Novo Testamento. Os A póstolos fazem a transição para a I greja, e daí se segue até os bispos. Por sua vez, bispos e monges fazem a ligação com a vida moral e com as artes e ofícios da vida material.

A catedral expressa uma idéia do mundo cristã que é essencialmente histórica, isto é, uma sucessão de fatos únicos, que só ocorrem uma vez: Criação, Queda, vinda do Redentor e história da I greja por el e fundada, até o Juízo Final - a partir do qual haverá apenas a eternidade e, portanto, o fim da história (tema, junto com o correlato fim das ideologias, que ainda hoje parece afligir algumas mentes).

0 percurso ao qual se é conduzido quando se experiencia a catedral também conduz ao Limbo "sem pena nem glória das crianças". Crianças inocentes, diria eu, como os selvagens pagãos. Batizar crianças ou converter pagãos é encaminhá- los para a eternidade atravessando a passagem da história. Como prossegue Gaos em sua interpretação,

É também uma idéia que se pode chamar "itinerária”, como de um caminho pelo qual, procedendo como as Pessoas divinas e Deus ... [o homem] volta semprea seu Criador no Céu, ou fica para sempre afastado Dele no Inferno. E itinerário duplo: porque não é só o grande itinerário histórico ... de toda a Humanidade até a "consumação dos séculos", mas também o itinerário individual de cada um dos membros da Humanidade ... ao longo desta vida terrena... ${ }^{33}$

M as, a catedral também expressa o que parece ser uma ligação entre o sagrado e o mundano. Vitrais foram doados por condes, príncipes e reis e não causa espanto, então, que se encontrem cenas de são João Batista com Eleonora da I nglaterra, esposa do rei de Espanha. A realeza se incluía, privilegiadamente, no "itinerário".

Na feliz expressão de Gaos, a catedral é um "catecismo plástico". Ele lembra Vítor Hugo, para quem a catedral era um livro. N um afresco do Petit Pa- 
lais de Paris, lê-se que a catedral é uma summa de pedra. E o tomista Sertillanges dizia que a Summa Teológica de Tomás de Aquino era uma "catedral escrita". O livro da catedral era a idéia de história vivida pelo homem de então.

Nos encontramos, pois, com uma construção ... destinada ao culto religioso por uma coletividade que, representando-se a si mesma nela, dá expressão à idéia do mundo que a anima ... a coletividade está integrada [na idéia do mundo] por um mundo sobrenatural ... [um] "outro mundo" ... A coletividade construtora da catedral de Chartres não foi integrada apenas pel os que intervieram em sua construção; iniciadores, arquitetos, operários, doadores a edificaram tão-somente como membros que vivenciavam [a coletividade] da I greja cristã, então dilatada no espaço até os confins com os infiéis e no tempo ... atéa consumação dos séculos. ${ }^{34}$

A coletividade cristã se estende, pois, até a eschatiá: no espaço, até o limite com os infiéis/pagãos, em certo momento vistos como os selvagens aliciados por Satã que ameaçam destruí-la; no tempo, até o embate final com o Anticristo.

Contudo, a partir do século XIV a história começa a se laicizar e vai se tornando mais precisa, como mostra a exigência do rei deAragão, em 1375, quanto à precisão com os detalhes e a consulta aos arquivos. Ao mesmo tempo, ela vai perdendo sua transcendência e seu caráter providencial e começa a caminhar do teológico para o político até chegar, já no Renascimento, a Maquiavel..$^{35}$

O que concluir, então, sobre a teoria da história na Idade M édia?

É preciso enfatizar um dado fundamental: nas Escrituras Deus não se re velou de uma vez por todas, mas pouco a pouco, no tempo, e o tempo se tornou essencial na relação Revelação- Redenção. Havia, pois, uma temporalidade, ainda que a essência da história estivesse fora do tempo. A extensão da Revelação no tempo construiu uma concepção histórica sui generis no interior mesmo do discurso teológico.

Se a noção medieval de história pode nos parecer hoje ingênua é preciso lembrar que foi com ela que se iniciou a concepção do tempo histórico, e dificilmente seria possível entender a história da história - vale dizer, a própria autoconsciência do O cidente cristão - sem reconhecer o significado do cristianismo.

O O cidente é uma civilização imersa na história e que se pensa através dela; por isso, o cristianismo medieval não foi irrelevante: 
Da época patrística à redação denisiana ... os documentos testemunham a importância atribuída ao tempo ... O homem medieval vive na história: a da Bíblia ou da igreja, a dos reis consagrados e taumaturgos. M as ele não considera nunca o passado como morto ... O passado toca-o muito de perto, quando o costume funda o direito, quando a herança se tornou legitimidade e a fidelidade uma virtude fundamental. ${ }^{36}$

H avia, então, uma vivência do passado, plena de sentido; havia uma devoção ao passado, como diz Ariès (1989). M as era uma devoção voltada para a redenção futura no final dos tempos. 0 homem medieval vivia na história, sim, mas como observou Gusdorf (1967), era uma história que tendia mais a um universalismo transcendental que ao significado do evento particular; a uma razão última para mais além dos homens e fora da história. Era uma história fundada nas Escrituras e estas eram a um só tempo indiscutível verdade sagrada e indiscutível verdade histórica.

Uma antropologia e uma história, tal como percebidas modernamente, não seriam possíveis no interior de uma teologia engl obante que não atribuía sentido ao particular.

0 transcendentalismo escatológico e a dificuldade de lidar com o particular dificultavam também o trato com a alteridade. A periodização cristã que dividia o mundo no tempo em antes e depois da Revelação, implicava também uma divisão no espaço, em dentro e fora da cristandade. Antes, pagãos idólatras; depois, cristãos. Dentro, cristãos civilizados; fora, pagãos selvagens. 0 conceito de cristandade como que toma o lugar do hemeros grego. $\mathrm{Na}$ "geografia teológica" medieval, o continente americano, previamente à chegada dos europeus-cristãos, seria um espaço "antes de Cristo".

Se não havia como tratar a al teridade localizada no espaço ou no tempo em seus próprios termos, existia, contudo, a noção de selvagem para dar conta de um Outro de difícil localização na gesta Dei.

Reduzindo a história a uma trilha providencial única, o pensamento medieval reduzia a alteridade ao paganismo e à selvageria ou barbárie. Tal pensamento era fundado na descrição bíblica da condição primitiva do homem, numa atitude mental de aderência acrítica às Escrituras que impedia qualquer distanciamento relativizante capaz de possibilitar uma "etnografia realista", para usar a expressão de Hodgen. ${ }^{37}$ Tudo que estivesse fora do quadro 
mental e teológico do período ou próximo dos limites do O rbis Terrarum só poderia ser monstruoso ou herético.

Naquele contexto de idéias, a percepção da alteridade tendia a favorecer uma "tradição" derivada de Plínio, o Velho, desde Pomponius M ela e Solinus, até $M$ andeville e outros. Todos el es se basearam em Heródoto, deformando 0 conjunto de sua obra. De H eródoto, apenas fragmentos de sua H istória ganharam circulação mais ampla no período medieval..$^{38}$

Os autores medievais pareciam desinteressados quanto aos usos e costumes mesmo dos selvagens próximos, preferindo repetir, de maneira deformada, descrições antigas relativas aos persas, egípcios, chineses, citas e outros. 0 pensamento medieval era indiferente aos bárbaros do norte e do oeste europeus, ainda não cristianizados, talvez porque o próprio homem europeu tivesse sido o bárbaro/selvagem da Antigüidade. No M edievo tal reflexão não existia e se dava preferência às monstruosidades "plinianas" que ocupavam lugar de destaque na literatura, nos sermões das igrejas e nas obras "científicas".

Provavel mente, as centenárias lutas contra bárbaros, muçulmanos e tártaros, não raro percebidas nos termos da gesta Dei como lutas contra o Anticristo, reduziram o que poderia ser uma curiosidade etnográfica às necessidades da sobrevivência. Até o século XVI foram poucos os esforços no sentido de um ol har livre da tradição herdada de Plínio, na direção dos modos de vida de outros povos, europeus ou extra-europeus. M issionários, comerciantes e peregrinos, além dos Cruzados, viajaram pela Europa, Ásia e África e certamente mantiveram contato com vários povos, civilizados ou selvagens. $M$ as os relatos eram bem mais lendários que realistas.

Letrados e iletrados, sem distinção, preferiam embeber suas mentes numa decocção rançosa de observações culturais feitas muito antes pel os antigos ... transmitidas de forma distorcida por uma sucessão de imitadores irresponsáveis. Fontes melhores foram desprezadas em favor de compilações e epítomes que continham uma mistura divertida de maravilhas e monstruosidades. Tendo perdido o contato com os clássicos, a erudição medieval fornecia um sedimento fabuloso e despropositado do que havia sido no passado uma etnografia comparativamente realista. ${ }^{39}$

Apesar da experiência de missionários e comerciantes, o fantástico predominava sobre o factual. 0 "pensamento etnológico" medieval era composto de fragmentos do conhecimento antigo, repetidos e copiados de um autor a outro, seguindo o modelo da "recapitulação pia", parte de uma atitude se- 
gundo a qual inexiste conhecimento novo. N essa recapitulação, espaço e tempo eram confundidos: o que havia sido dito sobre uma tribo asiática era tranqüilamente transferido para outra, africana, e o sentido do lapso temporal foi perdido. Já o próprio Tacitus, afinal, havia ainda na Antigüidade transferido para os germânicos aquilo que os gregos diziam sobre os citas. Parecia não haver consciência de que um povo descrito pelos antigos há mil anos poderia ter desaparecido, migrado para outro ambiente ou se transformado. Aqueles povos continuavam a ser descritos como se seus costumes permanecessem inalterados até que, al cançados pela evangelização, fossem incorporados à gesta Dei como estágios na trilha da salvação.

A H istoria Naturalis de Plínio, o Velho, continha informações geográficas, pois o autor era um estudioso e teve muitas oportunidades de obter informações, mas continha também coleções de supostas aberrações anatômicas com que o imaginário de sua época povoava o mundo não conhecido.

O que se fez nos séculos subseqüentes foi repetir Plínio, que deu muita importância às artes e ciências romanas, mas pouco se preocupou com usos e costumes dos povos com que manteve contato. Embora tivesse mencionado centenas de povos, localizados geograficamente, não foi capaz de distingui-los culturalmente, nem mesmo na Itália, ou na H ispania Terraconensis, onde viveu por alguns anos, nem na Germânia ena Criméia, por onde viajou.

Em compensação, não deixou de mencionar alguns imaginários povos monstruosos: os chineses (que, no entanto, abasteciam as mulheres da nobreza romana com produtos de beleza) eram parecidos com bestas selvagens; com relação à Í ndia, observou a divisão no que hoje identificamos como castas, mas de forma extremamente su perficial. Interessava-se mais pel o sobrenatural e bestial que pelo comum. Animais e humanos fabulosos competiam com o exoticismo na descrição de povos da África. Destes, uns se alimentavam de cobras e eram mudos; outros andavam nus e evitavam os estrangeiros; outros, ainda, viviam promiscuamente com suas mulheres; e havia os Blemmiae, desprovidos de cabeças e com olhos e boca no peito - que seriam mais tarde "vistos" na América, onde foram chamados de "descabezados". Todas essas características poderiam definir alguma forma de homem selvagem do imaginário medieval. Se Plínio privilegiava a anormalidade, nunca teve a curiosidade de indagar o que a teria causado. Além disso, não revelou nenhuma preocupação comparativa.

Pomponius M ela e Solinus, nos séculos subseqüentes, igualmente se ocuparam mais com um suposto anormal que com o normal, e suas fantasias percorreram todo o medievo. O De M irabilius M undi de Solinus foi explicitamen- 
te dedicado à exploração do fabuloso, do estranho. Até mesmo na cidade de Roma haveria mulheres de monstruosa fecundidade, ena Península Itálica existiriam lobos que fitavam as pessoas tornando-as surdas-mudas. Na Sicília existiriam fontes cujas águas curavam pernas quebradas. O s moscovitas se transformavam em lobos durante o verão, e seu Deus era Marte. Na Trácia, que absurdo, as mulheres não se casavam de acordo com a vontade dos pais, mas com aqueles homens que Ihes pareciam mais belos! Os trogloditas africanos, repete ele, comem serpentes e são mudos, além de não desejarem riquezas.

Seres normais pareciam ser excessivamente prosaicos, e seguramente 0 exótico e monstruoso atraía mais leitores num universo mental onde tudo que não fosse cristão escapava da normalidade. Os arimaspes só tinham um olho; os essedônios faziam taças com crânios humanos; os phanesianos tinham orelhas enormes com as quais envolviam o corpo, à maneira de vestimentas.

Plínio, M ela, Solinus e outros pouco mais fizeram além de copiar Heródoto em suas passagens menos rigorosas, acrescentando algumas referências aos selvagens da I rlanda ou da Gália.

O pensamento medieval, repito, não privilegiava a pesquisa independente. A sociedade era em larga medida estática, embora progressos técnicos tivessem sido feitos. A imaginação intelectual, englobada pela teologia, não era menos hierárquica que a sociedade: o mundo era encadeado na Grande Cadeia do Ser, onde o selvagem ocupava um lugar ambíguo. O s dogmas religiosos limitavam a imaginação criativa, até que se realizasse o "choque cultural" resultante do encontro com o ameríndio, ainda mais problemático que o africano já conhecido. A cultura trazida pela patrística, apesar de são Francisco de Assis, não percebia a natureza como algo significativo em si mesmo, mas como algo que deveria ser interpretado em termos salvacionistas. Além disso, se houve teólogos que duvidassem das descrições de povos fabulosos, a aderência à lógica escolástica, avessa à experimentação, reprimia a refutação a tais descrições (H odgen, 1964).

Conhecimentos novos eram possíveis, pois nunca deixou de haver viagens de comerciantes, aventureiros e missionários para além do mundo europeu-cristão. Entretanto, parecia haver uma recusa à aceitação dos fatos geográficos, do que resultava uma ignorância etnográfica.

A discussão sobre a forma da Terra tinha relevância para a teologia, tanto quanto para a apreciação da alteridade. Se havia quem aceitasse a concepção pitagórica da esfericidade da Terra, com suas várias zonas climáticas, teólogos como o Venerável Beda e santo Agostinho a rejeitavam. Lactâncio e 
outros representantes da patrística reafirmavam que a Terra era chata. Ademais, beirava a heresia afirmar a possibilidade de que os descendentes de Noé pudessem habitar toda a superfície do planeta. Para aqueles que imaginavam a Terra chata como um disco, não poderiam existir antípodas; como dizia Lactâncio - e sua opinião era amplamente compartilhada - seria ridículo imaginar que na outra face da Terra a chuva caísse de baixo para cima, ou que existisse uma raça humana vivendo de ponta-cabeça!

Já para os adeptos das zonas climáticas - septentrionalis frigida, temperata nostra, torrida, temperata antipodum, australia frigida - a zona equatorial seria inabitada, além de constituir uma barreira para quaisquer migrações na direção do hemisfério Sul, em decorrência das águas ferventes do oceano e do clima tórrido das terras; seria impossível que os descendentes de Adão a tivessem atravessado. Pior ainda: se o tivessem feito, como poderia até eles chegar a palavra de Cristo?

Com relação à geografia teológica medieval, a única al ternativa possível, no quadro intelectual da época, seria uma teoria poligenética da origem humana (que continuaria a ser tema de sérias discussões por muitos séculos), mas um tal ponto de vista seria incompatível com a perspectiva providencialista/escatológica da história de uma humanidade única; seria, ademais, intolerável: como manter o princípio fundamental de que Cristo morrera para salvar toda a humanidade e para que a Palavra fosse levada a todos, se metade da humanidade - a metade austral - vivesse sem comunicação com a outra, dela separada pelos mares ferventes? Como pensá-la nos termos de uma trilha única a ser seguida pela humanidade?

Para santo Agostinho, era absurdo imaginar que os descendentes de Adão tivessem navegado através do imenso O ceano, indo povoar o outro lado da Terra. No entanto, a Cidade de D eus se ocupa com outro problema característico da I dade M édia: teriam os filhos de N oé originado as raças monstruosas, inclusive os antípodas, descritas em tantos textos? Santo Agostinho termina optando por uma inconclusão monogenética: ou os relatos são falsos ou, se tais seres existem, não são humanos, ou então, se o são, não são descendentes de Adão. A questão era sempre a mesma: como incluí-los na Grande Cadeia do Ser e na gesta Dei?

Apesar do contato com "bárbaros selvagizáveis" em vários pontos do mundo, o pensamento patrístico era pouco interessado em culturas estranhas, desinteresse que se prolongou por boa parte da I dade M édia. Ao longo desta, descrições etnográficas foram feitas, mas com o propósito de confirmar as Escrituras e contrastar os povos exemplares, isto é, cristãos, com as 
monstruosidades da fronteira bárbara/selvagem; as virtudes com as iniqüidades. Eram, ademais, formalizadas e repetitivas, numa antropogeografia a mais resumida possível queignorava, como dito antes, o tempo, congelando os costumes e agrupando povos diversos num mesmo rótulo. Essa antropogeografia terminou por se cristalizar a ponto de ser utilizada para explicar os povos do Novo Mundo.

Esse parece ter sido o espírito "etnográfico" (ehistórico) medieval, desde Isidoro de Sevilha, no século VII (Etimologiae) até Bartolomeu da Inglaterra, no século XIII (DeProprietatibus Rerum); de Brunetto Latini, conselheiro de Dante (Li Livres dou Tresor); de M andevillle (Imago M undi) e tantos outros.

A percepção do mundo de Isidoro era fortemente limitada ao M editerrâneo e seu propósito era o de educar os visigodos, que dominavam a Espanha, quanto aos princípios do cristianismo. Sua enciclopédia etimológica continha informações sobre línguas e raças; povos monstruosos; a origem da idolatria e a diversidade de costumes. Sua imagem do mundo era aquela dominante na cosmografia medieval: uma grande ilha, o O rbis Terrarum, circular como uma roda, dividida em três partes, Europa, Ásia e África, cercada pelo $O$ ceano. No entanto, I sidoro admitia a possibilidade de uma quarta parte da Terra, para o sul, habitada pelos antípodas.

Para Isidoro, as tribos da humanidade haviam sido separadas pela diferenciação de línguas que se seguiu à construção da Torre de Babel. As diferenças culturais foram por ele tratadas de forma estereotipada e superficial: os germanos tinham grande estatura; os saxões eram bravos; os bretões, estúpidos, e assim por diante. As diferenças climáticas explicavam as diferenças de temperamento: os romanos eram dignos; os gregos, instáveis; os gauleses, selvagens e ferozes.

M onstruosidades, como seria de esperar, ocupavam sua imaginação. Além de indivíduos monstruosos, ele acreditava em povos monstruosos, extraídos da literatura teratológica clássica: gigantes, anões, ciclopes, hermafroditas e cinocéfalos, entre outros, habitantes de lugares remotos como a Líbia e a Índia.

As religiões da humanidade eram divididas em duas categorias: idólatras (pagãos) e cristãos. 0 primeiro rótulo agrupava egípcios, cretenses, mouros, italianos, romanos e outros. Sua explicação para a idolatria foi copiada do grego Euhemerus: o sentimento de perda com relação aos mortos fazia que os homens criassem imagens à sua semelhança; gradativamente, aqueles que, de início, eram apenas lembrados e reverenciados, foram sendo deificados em conseqüência do erro, central para uma teologia da Queda. 
Dadas ... as qualidades da mente patrística ... o livro pou co mais é do que ... uma miscelânea de conhecimentos, uma compilação de compilações ... Ele revela o quão escassa era a informação no início da I dade M édia, mesmo entre homens educados. Ao mesmo tempo, a influência de Isidoro sobre aqueles que o seguiram foi muito grande. Era rara a biblioteca de capela ou de abadia cujo catálogo não incluísse seu nome. As Etimologias continuaram sendo citadas como uma autoridade até 0 século XIII. ${ }^{40}$

No século XIV temos M andeville, provavelmente o mais conhecido produtor de maravilhas e monstruosidades. Suas Viagens, de 1356, foram escritas após o fechamento do M editerrâneo pelos sarracenos e destinavam-se a informar os europeus, impossi bilitados de viajar, sobre os costumes e diversidades dos povos, e as diversas formas dos homens e bestas. Tanto quanto seus antecessores preocupava-se com a diversidade humana - questão fundamental para a Antropologia - mas ela era tratada de forma mais teratológica que etnológica.

Seus relatos são compilações a partir de Plínio, M ela, Solinus, Isidoro; de romances e bestiários. Os al baneses são albinos, como o eram em H eródoto. As amazonas habitavam a ilha das Fêmeas; numa ilha localizada no $\mathrm{M}$ ar O ceano vivia um povo que pendurava seus parentes doentes em galhos deárvores para al iviar sua dor, e em seguida os devoravam. Na ilha de Lamaria vivia um povo - que iria reaparecer em M ontaigne, Shakespeare e outros - cujos costumes eram o oposto dos europeus: nus, canibais, partilhavam as mulheres e outros bens entre si.

Até mesmo os grandes cosmógrafos do século XVI, como M ercator, foram incapazes de criticar as fantasias medievais, mesmo sabendo que vários relatos eram inverídicos. A Cosmographia de Muenster, de 1544, usava as mesmas ilustrações que compunham as Viagens de M andeville.

$\mathrm{Na}$ medida em que se ocupava com a diversidade dos povos, $\mathrm{M}$ andeville se preocupava com uma questão central para o pensamento cristão: a diversidade das religiões em face de uma humanidade única, começando com os gregos e terminando com a "religião natural" dos brâmanes. M as, caracteristicamente, não era capaz de entender a "idolatria" senão como o produto de mentes distorcidas, e mentes distorcidas eram atributo do selvagem. No quadro mental da Idade M édia, dominado pela verdade cristã, nenhuma outra interpretação seria possível.

Como diz Le Goff: 
Ao contrário das pessoas do Renascimento, as da Idade M édia não sabem olhar, mas estão sempre prontas a escutar e a acreditar em tudo o que se lhes diz. Durante as suas viagens, embebedam-nos com relatos maravil hosos, e eles crêem ter visto o que souberam por ouvir dizer. Empanturrados com lendas que tomam por verdades, trazem consigo as miragens e a sua imaginação crédula materializa-Ihes os sonhos ... mais ainda que em suas terras, eles se tornam os sonhadores acordados que foram os homens da Idade M édia. ${ }^{41}$

E como observa White (1994), a compreensão de alteridades aparentemente radicais numa humanidade apenas superficial mente diversa não era possível em civilizações "teonômicas"; certamente era difícil para o pensamento medieval, que dispunha apenas de uma linguagem teológica e que havia herdado concepções hebraicas que permitiam a leitura do diferente como maldito. Se o cristianismo criou uma humanidade única, ele não obstante opunha uma humanidade plena, acabada, a uma humanidade potencial, capaz apenas de realizar-se plenamente pela inclusão na cristandade.

Voltemos à herança greco-hebraica. N a tradição hebraica, tanto quanto na grega, o selvagem é associado ao deserto, lugar do vazio e da desolação, do caos (mais tarde redefinido como o lugar do desconhecido, outra forma de vazio, como nos mapas da transição do medievo para o século XVI). 0 deserto, tanto quanto a floresta, é a região selvagem, lugar de terra inculta; mais do que isto, no caso do deserto, incultivável - e vale ressaltar a relação semântica entre cultivo e cultura, presente tanto no pensamento grego como no hebraico. Para os gregos, a selvageria dos citas relacionava-se estreitamente com o deserto de seu país e com um modo de vida nômade que se contrapunha à polis. Na tradição hebraica, por sua vez, ambos são aspectos da mesma condição maligna/maldita.

O selvagem se opõe ao bem-aventurado: enquanto este prospera e faz as coisas crescerem (é agricultor sedentário), o selvagem mal dito destrói (caçador), éerrante (nômade), feio e violento. Feiura eviolência são provas da maldição. A conjunção das duas tradições de pensamento tendeu a fundir condição física e condição moral; homem selvagem elugar selvagem (White, 1994).

0 homem selvagem é o que se rebelou contra Deus; nômade e gigante, abaixo da animalidade. Ele representa a corrupção da espécie. É a desordem; em contraposição às espécies perfeitas e puras da ordem, representa a mistura do que deveria ser separado, tal como o hibridismo no pensamento grego 
também remetia à impureza e ao selvagem (Woortmann, 2000). U m exemplo é o gigantismo (a existência de gigantes poderia ter sido o motivo que teria levado Deus a provocar o Dilúvio).

Selvagens seriam também os descendentes de Cam, imaginados como negros, pela associação entre a cor negra e a maldição. N emrod, caçador, teria sido descendente de Cam. M aldição - selvagem - caçador - errante. Santo Agostinho iria associar N emrod à fundação de Babel e à diferenciação racial/lingüística. Confusão lingüística e aberração física seriam atributos do selvagem.

H erdeiro dessa tradição, o pensamento medieval, imerso numa percepção teológica do mundo segundo a qual o próprio universo físico era ordenado por princípios morais/finalistas, e numa concepção escatológica da humanidade, tendia, como disse, a dividir o mundo em cristãos e pagãos civilizados e bárbaros/selvagens, o que equivale a dizer dentro da história e fora da história. Enquanto a humanidade cristã progride, guiada pela $\mathrm{M}$ ão divina, fora dela impera a degeneração, possivelmente por obra de Satã.

No entanto, a Europa teve contato com outros continentes e com povos que não eram nômades a vagar pelo deserto. Mercadores, soldados e missionários devem ter tido uma visão mais sensata da diversidade cultural. Como sugere Hodgen (1964), os mercadores certamente conheciam, pelo menos, aqueles aspectos culturais relacionados com os produtos trocados. Precisavam, por certo, se comunicar com os povos visitados e, de fato, fal avam árabe, persa, latim e grego, além de línguas eslavas e dos povos francos. Através de intérpretes, comunicavam-se com os habitantes da Í ndia e de outros lugares remotos. Os missionários seguramente conheciam al go das culturas "pagãs", pelo menos no que dissesse respeito ao esforço de conversão. Certamente uns e outros saberiam distinguir os costumes observados das fantasias do imaginário europeu; tanto os interesses comerciais quanto os evangelizantes requeriam um mínimo de objetividade relativa ao bárbaro/selvagem da África, da Ásia e da própria Europa.

Portanto, se cosmógrafos e cartógrafos, ainda após o término da I dade M édia, continuavam a repetir as fantasias de Plínio, Solinus ou M ela, não o faziam por falta de informações ou por barreiras lingüísticas.

No século XIII os mongóis ameaçavam a cristandade. Suas incursões foram percebidas como a realização da profecia da chegada do Anticristo e do fim do mundo. Eram imaginados como canibais e mensageiros do inferno. Curiosamente, com sua retirada, houve uma mudança de atitude relativa aos muçulmanos. M enos "selvagens", talvez, que os tártaros, e dado um melhor 
conhecimento da doutrina islâmica, deixaram de ser acusados de idolatria e paganismo, para serem definidos como hereges, a serem recuperados para 0 cristianismo. Iniciou-se uma nova fase de proselitismo que teve como um de seus componentes o ensino do árabe na Universidade de Paris e no Colégio de M iramar, em M ajorca. E a própria M ongólia foi objeto de interesse da I greja, que para lá enviou frei Carpini efrei Rubruck. Por sua vez, Marco Polo realizou sua famosa estada junto a Kublai Khan, que sugeriu ao papa o envio de sábios que o convencessem a adotar o cristianismo. I ronicamente, se missionários e mercadores percorriam Catai e outros lugares, o faziam protegidos pela "pax tartarica".

O relato de Carpini, H istoria M ongolorum, é uma descrição certamente etnocêntrica, como nas referências a tradições "ridículas", e na incompreensão das concepções de exogamia e da terminologia de parentesco: os homens, escandalizava-se ele, casavam com todas as mulheres, inclusive suas irmãs pelo lado da mãe e com a esposa do pai após o falecimento deste; seguramente, uma conduta nada recomendável desde a óptica da moral cristã e sua concepção de incesto. No entanto, ele levantou questões de interesse antropológico: características físicas, atividades econômicas, habitações, alimentação, padrões matrimoniais, crenças e rituais religiosos e formas de herança, por exemplo.

Rubruck foi também em parte etnocêntrico, assimilando simbolismos bu distas aos cristãos quando descrevia "rosários", "altares" ou “imagens semelhantes a bispos distribuindo bênçãos". Tanto ele como Carpini parecem ter sido menos dados a fantasias e a mirabilia que M arco Polo, por sua vez mais realista que a literatura patrística. $M$ as mesmo $\mathrm{M}$ arco Polo, que teria vivido durante 17 anos a serviço de Kublai Khan, forneceu poucas descrições etnográficas, como ressaltam Le Goff ${ }^{42}$ e Hodgen (1964).

Sintomaticamente, todos os três foram em larga medida esquecidos nos séculos seguintes, em contraste com as fantasias "maravilhosas" de M andeville, se bem que Colombo conhecesse o Liber Diversorum de M arco Polo; que o relato de Carpini fosse incorporado ao Speculum Historiale de Vicente de Beauvais e que Rubruck chegasse a influenciar Roger Bacon, em seu O pus $M$ aius (só tornado mais conhecido no século XVI), ainda que por razões pragmáticas: missionários fracassavam em seus empreendimentos porque desconheciam os ritos de outros povos. M as Bacon, influenciado pelo supostamente aristotélico Segredo dos Segredos, explicava as diferenças culturais como efeito de influências astrológicas e propunha que o seu entendimento seria alcançado precisando-se a latitude e longitude de cada lugar. 
Essas concepções explicativas da alteridade conviviam com as imagens transmitidas pela série de repetições do bestiário "pliniano" e com a concepção de selvagem herdada da tradição hebraica, o que poderia explicar a pequena repercussão de descrições mais realistas. M ais do que isso, selvagens bestiais, eventualmente associados a Satã, eram necessários à própria teoria da história da humanidade è identidade cristã.

M as, como mostra White (1994), o cristianismo impôs certas transformações relativas à concepção hebraica: no lugar de uma maldição irremediável, a Redenção. 0 remédio representado pelos Sacramentos propiciava uma atitude mais caridosa (em tese) em face dos que caíram para o estado selvagem. Contudo, era uma piedade etnocêntrica/teocêntrica - o universalismo cristão tinha uma I greja que aceitava os homens apenas em seus próprios termos; a Queda podia ser perdoada, desde que se aceitasse a autoridade da I greja. Por isso, não obstante a piedade, os povos selvagens só mereciam atenção como candidatos à conversão; nunca em seus próprios termos.

No entanto, é importante o princípio de que todos os homens poderiam ser salvos: independentemente da degeneração física, a alma permanecia em estado de graça potencial. Somente D eus sabe quem pertence à sua Cidade; por isso mesmo os homens mais repugnantes deveriam ser objeto do proselitismo evangelizador. Monstruosos, como aqueles descritos pelos antigos, mas potenciais membros da Cidade de Deus, visto que não deixavam de possuir uma humanidade essencial. Redimidos pela graça, seriam inscritos na história qualitativa medieval. Em comparação com o ponto de vista hebraico, a relação entre aparência física e atributos morais era atenuada; por influência do pensamento grego tendia-se mais à distinção entre essência e atributo que à fusão dos dois. Afinal, todos descendem do "protoplasma único". ${ }^{43}$

Para a teologia cristã, o homem selvagem e/ou monstruoso era um problema sério: não se podia admitir uma falha no poder criador de Deus, o que poria em dúvida todo o sentido da gesta Dei, nem uma atitude por parte Dele que não fosse conforme ao princípio da caridade. Para Tomás de Aquino apresentava-se, então, um problema: um homem selvagem com a alma de um animal seria tão degradado que estaria além da possi bilidade de redenção; um homem com alma de animal deveria ser tratado como animal, mas os Evangelhos ofereciam a salvação a todos que possuíssem uma alma humana, apesar do aspecto físico. Se os pecadores de Dante tivessem sido homens selvagens sem alma humana, não estariam em nenhum círculo do inferno, mas seriam guardiães do inferno! ${ }^{14}$ 
No pensamento medieval existiram várias formas de homens selvagens e, como também para os gregos, podiam tanto existir indivíduos selvagens, próximos à civilização/cristandade, quanto povos selvagens, distantes mas que por vezes se aproximavam ameaçadoramente. Porém, selvagens imaginados existiram tanto fora como dentro da Europa. Os povos do norte europeu ou da I rlanda não eram menos selvagens, maravilhosos ou monstruosos que os da África ou Índia.

Le Goff observa que, apesar das viagens e da redescoberta de Ptolomeu, em 1406, o O cidente continuou a ignorar a Índia e o oceano Índico, como mostram o mapa-múndi catalão da Biblioteca Estense e o planisfério de frei M auro de M urano, ambos do século XV. Foi só depois das navegações portuguesas que o conhecimento geográfico do oceano Índico, até então considerado um mar fechado, começou a se precisar.

0 mare clausum era o reino onírico das fantasias medievais, o hortus conclusus de encantamentos paradisíacos e de pesadelos. "Abra-se, rasgue-se nele uma janela, um acesso, e logo o sonho se desfaz". 45

Para os medievais, o oceano Índico era o resultado das construções helenísticas. 0 próprio Ptolomeu havia cedido ao imaginário da poesia épica indiana que iria se vulgarizar na imaginação medieval. Se santo Agostinho era cético com relação a tais fantasias, não deixou de recear, em suas reflexões sobre o Gênesis, a possi bilidade da existência de seres monstruosos na Índia. Como incluí-los na descendência de N oé? Seriam talvez modelos criados por Deus que explicariam as aberrações vez por outra observadas no próprio Ocidente cristão?

A "mitologia indiana" foi enriquecida com a personagem de Preste João que, em 1164, teria enviado uma carta ao imperador bizantino Comneno. Note-se que a Índia se fundia com a África (a Etiópia seria parte da Índia meridional); o reino de Preste João foi inicialmente localizado na Índia propriamente dita, e em 1177 Alexandre III enviou um emissário portador de uma carta para Johanni Illustri et magnifico Indorum regi. No século XIV ele foi transferido para a Etiópia.

Os ciclos romanescos realimentavam a imaginação, associando o maravilhoso teratológico à aventura, à busca. É o caso do Romance de Alexandre. É nesse contexto que se redescobre, por exemplo, o texto de M egasthènes ( 300 a.C.) sobre as maravilhas da Índia.

Essa Índia, principalmente as ilhas do oceano Índico, tinha vários signi- 
ficados. De um lado, era o mundo da riqueza (especiarias, pedras e madeiras preciosas) contraposto ao O cidente cristão - latinitas penuriosa est. Eram as "ilhas afortunadas", das quais a mais rica era a Taprobana (Ceilão), mais tarde presenteno épico de Camões.

A Índia referida por Le Goff era o lugar também de mundos místicos, terras de santos que se mantiveram puros, imunes às tentações. E era terra de monstros, que serviam ao 0 ci dente para escapar de sua mediocridade faunística para reencontrar o poder criador de Deus. Santos e monstros já eram duas versões do selvagem ao final da I dade M édia: o bom selvagem, que mais tarde iria alimentar o pensamento social ocidental, e o selvagem monstruoso.

Essa Índia era o sonho europeu:

Sonho que se expande na visão de um mundo de vida diferente, onde os tabus são destruídos ou substituídos por outros, ondea extravagância segrega uma impressão de libertação, de liberdade. Perante a moral acanhada imposta pela I greja, expande-se a sedução perturbadora de um mundo ... onde se pratica a coprofagia e o canibalismo; da inocência corporal, onde o homem liberto do pudor do vestuário reencontra o nudismo; a liberdade sexual, onde o homem, desembaraçado da indigente monogamia e das barreiras familiares, se entrega à poligamia, ao incesto, ao erotismo. ${ }^{46}$

É bem possível que uma Índia imaginada estimulasse as fantasias medievais tanto quanto a crença em bruxas, também devotadas à liberalidade sexual.

A Índia era também o sonho do medo cósmico, tanto quanto o lugar do Anticristo, das raças malditas do fim do mundo guardadas por Gog, rei de Magog, possivelmente o lugar dos citas, descritos por Heródoto (mas por ele e por H ipócrates localizados no N orte, na Europa). Essas mesmas raças foram depois "transferidas" para o continente americano recém-encontrado.

E era uma utopia cristã, evangelizada por são M ateus, são Bartolomeu e santo Tomás (a busca do túmulo desteúltimo era parte de um imaginário sagrado-aventureiro medieval mais amplo). Era o lugar do Preste João, que ganha foros de verdade com a descoberta de uma comunidade nestoriana. Como sonho cristão, no dizer de Le Goff (1980) , éo caminho para o Paraíso Terrestre, pois é de lá que partem os quatro rios paradisíacos que a imaginação identifica com o Tigre, o Eufrates, o Ganges e o Nilo. 0 mapa de Beatus localizava o Paraíso nos limites da Índia (Colombo iria localizá-lo no Orenoco).

Era finalmente, como disse, o mundo do bom selvagem; o paraíso de uma 
I dade de $\mathrm{O}$ uro, de uma humanidade feliz anterior ao pecado original, como no $O$ pus M aius de Roger Bacon e no DeVita Solitaria de Petrarca. Foi nesse Paraíso Terrestre que Preste João teria se banhado na fonte da juventude; ali teriam existido as árvores-oráculo já mencionadas por Solinus. Naturalmente, se tal humanidade era anterior ao pecado original, as Índias constituíam um problema teológico: como incluir tais povos na gesta D ei, isto é, na história?

O O ceano Índico era o oposto do M editerrâneo: neste, a civilização; naquele, o selvagem puro ou monstruoso, por ambas as razões, fora da história. A iconografia parecia espelhar uma concepção da Índia como antinatura, parte do espírito anti-humanístico medieval. M as, observa Le Goff (1980), havia também uma tendência mais racional, buscando domesticar as maravilhas teratológicas. Santo Agostinho e Isidoro de Sevilha interpretavam-nas como casos-limite da natureza, parte da ordem natural e divina. M ais tarde, a partir do século XII, foram transformadas em alegorias moralizantes que tentavam dar um sentido ao extravagante, moralizar o exótico: os pigmeus são então interpretados como símbolo da humildade; os gigantes como símbolo do orgulho e os cinocéfalos como símbolo de pessoas quesilentas. "A domesticação processa-se ao longo de uma evolução que transforma as alegorias míticas em al egorias morais ... até o nível da sátira social". ${ }^{47}$ Num manuscrito do século XV, os homens monstruosos da Í ndia aparecem vestidos como burgueses flamengos.

Le Goff percebe nesse imaginário duas mentalidades, nem sempre claramente separadas:

Por um lado, e o cristianismo, pelo jogo da explicação al egórica ... reforçou tal tendência, trata-se de maravilhas domadas, conjuradas, postas ao alcance dos 0 cidentais, transportadas para um universo conhecido. Feita para servir de lição, esta Índia moralizada pode ainda inspirar medo ou inveja, mas é, sobretudo, triste e entristecedora. As belas matérias já não passam de tesouro alegórico, e os pobres monstros, feitos para a edificação, parecem todos eles repetir, com a raça infeliz dos homens maus, com o grande lábio inferior caído em cima deles, o versículo do Salmo CXL que personificam: malitia labiorum eorum obruat eos. Tristes trópicos... ${ }^{48}$

No século XII , as raças monstruosas iriam representar a degradação da humanidade após a Queda. M as a Índia também

É a transferência dos complexos psíquicos ... para o plano da geografia e da civilização ... A Índia éo mundo dos homens cuja língua não compreendemose 
a quem recusamos a palavra articulada ou inteligível e até mesmo toda a possibilidade de falar ... Desde a Antigüidade grega, o monoculismo é o símbolo da barbárie no Ocidente, e os Cristãos medievais povoam a Índia de Ciclopes. ${ }^{49}$

Para enten der a atribuição de selvageria a diferentes povos, inclusive europeus, é preciso recorrer ainda à mitologia européia relativa ao homem selvagem, o homo sylvaticus.

O homo sylvaticus medieval, habitante da Europa, era muitas vezes imaginado como vivendo próximo ao mundo civilizado, desde um ponto de vista espacial, mas longe, desde um ponto de vista simbólico. N ão se afastava muito do selvagem do imaginário grego antigo, habitante do agrios, espaço simbólico que se opunha à polis. 0 agrios grego era o espaço silvestre/selvagem com a mesma conotação dada pelo imaginário medieval de limite do mundo cultivado..$^{50}$

O homem selvagem medieval podia ser imaginado com um tipo físico muito próximo daquele do europeu, com uma exceção: seu corpo era coberto de pêlos. M as era também representado como gigante ou como anão, e nisso, como em outras características, partilhava do bestiário da "etnografia pliniana". M esmo já avançado o século XV o Liber chronicarum ad inicia mundi de Schedel, referido por Bartra, ${ }^{51}$ apresenta ilustrações de raças monstruosas do Oriente com características semelhantes às do homem selvagem mítico europeu.

É importante observar que esse homem selvagem não é uma transposição de características atribuídas a africanos ou asiáticos. Ele preexistiu ao contato com povos da África ou da Ásia; tanto quanto o "selvagem" grego, ele foi inventado antes para ser depois, eventualmente e de formas diferenciadas, aplicado a africanos e asiáticos, tanto quanto a europeus e, mais tarde, aos ameríndios. Contudo, ele podia por vezes ser descrito com as características dos mouros, ${ }^{52}$ como no Cavaleiro do leão de Chrétien de Troyes, ou como um negro com características de ciclope.

Em algumas representações ele exemplifica o poder miraculoso de Deus, capaz de quebrar suas próprias leis. M ais do que isso, o homem selvagem que habitaria as florestas da Europa significava para santo Agostinho uma mensagem que nos adverte que D eus fará o que ele profetizou para o fim dos tempos.

Bartra (1994) sugere que o mito do homo sylvaticus servia para prover um modelo capaz de resolver uma contradição. A teologia medieval não era 
capaz de admitir uma teoria gradualista que mediasse a oposição absoluta entre o humano e o animal, a continuidade entre o homem ea besta, incompatível com a concepção hierárquica da Grande Cadeia do Ser. Nesse quadro, a lógica simbólica do "homem selvagem", meio animal e meio humano, fornecia um vínculo entre humanidade e natureza, rigidamente separadas pela teologia; um ser liminal que operava a mediação entre opostos.

A dificuldade teológica era também uma dificuldade histórica, na medida em que existiam não apenas indivíduos selvagens, mas povos selvagens. De certa forma, várias representações do homo sylvestris já sugeriam a possibilidade de existência desses povos: se para os gregos existiam povos ciclopes ou centauros ( metáforas de bárbaros "selvagens"), na Europa medieval existiam famílias silvestres, idílicas ou não, tanto quanto povos inteiros.

Em outra vertente, na impossibilidade de admitir uma teoria gradualista e de admitir uma criatura semibestial, semi-humana, freqü entemente se recorria à al ternativa de explicar o selvagem pela demonologia. Indivíduos ou povos selvagens/monstruosos seriam criaturas de Satã.

H avia muitas representações do homem selvagem europeu. Em algumas, como em santo Agostinho, ele teria sido criado por Deus; em outras,

os escritores medievais ... preferiam evitar explicações teológicas para a existência de homens selvagens ... preferindo descrevê-los em termos sociológicos ou psicológicos: os homens selvagens, em sua lamentável condição, não seriam uma criação de Deus, mas criaturas que teriam caído nessa condição bestial devido à loucura, por terem crescido entre animais, pela solidão, ou pelos sofrimentos por que passaram. Para muitos pensadores, não existia um ser selvagem, senão uma existência selvagem ... Contudo, as explicações intelectuais não apagaram da imaginação medieval a presença de um ser meio homem, meio besta, numa posição similar à dos anjos que, na Grande Cadeia do Ser, eram situados entre os homens e Deus. ${ }^{53}$

Esse homem selvagem habitava as florestas cercado de bestas e vivendo como elas.

o hábitat do homem selvagem era constituído daquela noção de natureza única e escorregadia que a cultura medieval recriou a partir dos gregos. [A natureza] era um espaço inventado pela cultura para estabelecer uma rede de significados supostamente externos à sociedade, mas que permitia a reflexão sobre o sentido da história e da vida dos homens na Terra... O homem selvagem mantinha uma 
relação com a natureza que, por analogia, prescrevia um cânone de comportamento social e psicológico ... Ele era o homem natural, simetricamente oposto ao homem social cristão..$^{54}$

Selvagem e natureza se fundiam numa mesma síndrome do pensamento ocidental. De fato, tal pensamento exigia, como continua exigindo até hoje, a categoria natureza para tornar possível pensar a sociedade. Basta lembrar H obbes no século XVII e Lévi-Strauss nos tempos atuais; cada um deles constrói, à sua maneira, um edifício teórico a partir de um "estado de natureza" claramente selvagem, oposto à cultura ou à vida em sociedade.

Símbolo construtor do mundo cristão, o selvagem era ele mesmo pagão, não no sentido de al guém que recusa a palavra de Cristo, mas de alguém que a desconhece, seja por nunca a ter ouvido, seja por se ter tornado incapaz de ouvi-la. Na língua inglesa ele pode ser definido como heathen, palavra que podia significar pagão, selvagem, idólatra, gentio, bárbaro. Antes de ser abarcado pela demonologia, embora monstruoso, era mais um "homem natural" que um demônio. Contrapunha-se à sociedade mais como humanidade bestial que como força demoníaca ( significativamente, era percebido como estuprador). Porém, terminou sendo cristianizado pelo pensamento teológico que o transformou em sinal demoníaco; assim, por exemplo, a "mulher selvagem" veio a ser transformada em bruxa e os sarracenos infiéis em selvagens.

Em al gumas representações o homem agreste vivia em isolamento, o que era atribuído à loucura, e assimilado ao melancólico e ao maníaco, igualmente solitário, cabeludo, agressivo. Era, ademais, desprovido de pensamento:

desde um ponto de vista neoplatônico ou tomista o homem selvagem despedaçava a ordem cósmica, uma estranha e inexplicável ruptura ... 0 vazio que deveria estar ocupado por uma alma estava cheio de tendências como a solidão, a liberdade e o prazer e nenhuma delas tinha lugar na ordem hierática e hierárquica da cristandade. ${ }^{55}$

O indivíduo selvagem europeu foi se transformando ao longo do tempo, assim como se transformava o ser maravilhoso da Índia mencionado por Le Goff. Ao final da Idade M édia ele já podia ser visto tanto como representante de um "estado de natureza" idílico quanto como ser bestial. Esse duplo caráter não parecia tão distinto daquel e construído pel o imaginário grego, como nos mostra a representação dos centauros em seu encontro com Heraclés (Hartog, 1980). Tanto podia ser violento ecruel como possuidor de uma "bon- 
dade natural", característica que passou a assumir em meados do século XV quando o humanismo exigia um repensar da sociedade. Assim, ele era o que a história o fazia ser, não apenas como produto da história, mas como componente da própria idéia de história. 0 selvagem se transforma com o tempo em ainda outro sentido e, já desde o século XII, o imaginário popular o torna protetor das florestas e dos animais, assim como dos camponeses, freqüentemente retratados pela elite como selvagens eles mesmos. Para uma parte da sociedade, ele se torna benéfico, talvez numa recuperação de idéias pagãs anteriores à cristianização.

Ainda na I dade M édia o selvagem foi a personificação da noção de "economia natural", central, como é sabido, para a elaboração das teorias de uma futura ciência econômica. Como tal, era um ser paradoxal: desconhecia o fogo e comia al imentos crus, colocando-se pois no pólo da natureza; mas conhecia instrumentos e/ou armas, ainda que rudimentares, o que lhe atribuía cultura. Bartra (1994) ressalta a ambigüidade com que foi representado, já no Renascimento, por Paracelsus: os Wilde M enschen, Waldleuten ou Sylvestres não eram intrinsecamente diferentes dos homens porque também tinham que trabal har, mas Paracelsus queria distingui-los dos animais tanto quanto dos humanos: humanóides não descendentes de Adão, desprovidos de alma, mas não animais. Parecelsus se defrontava com o mesmo dilema que afligira santo Agostinho.

Como foi visto, o selvagem surgiu no imaginário medieval muito antes que a presença dos bárbaros, mongóis ou sarracenos se fizesse sentir, assim como havia surgido no imaginário grego antes do contato mais intenso com os bárbaros de então. Contudo, à medida que os povos bárbaros se constituíam em ameaça ao telos cristão, por serem recalcitrantes ao esforço evangelizador ou porque atacavam a Europa, como os mongóis, o selvagem foi também, tal como os centauros dos gregos, se transformando em "alegoria do bárbaro". Assim, H eathen tanto podia significar pagão como bárbaro. Se o selvagem começou sua carreira como simplesmente desprovido de religião, ser da natureza, el e foi freqüentemente transformado em inimigo do cristianismo por aderir a uma religião fal sa; num obstáculo à realização da gesta Dei.

O homem selvagem se aproximava do bárbaro por não possuir linguagem; mais corretamente, possuía uma linguagem de sinais e grunhidos semeIhante à dos animais, uma linguagem que podia expressar sentimentos mas não idéias.

Entre povos selvagens e indivíduos selvagens havia uma diferença: o "indivíduo selvagem" vivia sozinho, incapaz até de relações familiares. Era exem- 
plo da degeneração em que o indivíduo poderia cair pela perda da graça ou da razão. 0 povo selvagem, coletivamente caído - e muitos povos da Europa ainda não cristianizada eram assim percebidos - era uma ameaça à normalidade social.

O bárbaro selvagem era localizado longe da civilização/cristandade e "repleto de possibilidades apocalípticas para a humanidade civilizada. Quando surgem as hordas bárbaras ... os profetas anunciam a morte da era antiga e o advento da nova”. ${ }^{56} \mathrm{O}$ “indivíduo selvagem", pel o contrário, estava sempre próximo; cheio de pêlos, negro e deformado, gigante ou anão, habitava a floresta, o deserto ou a montanha, isto é, lugares inóspitos; vivia em cavernas, de maneira semel hante aos povos trogloditas e roubava mulheres e crianças. $\mathrm{M}$ as havia uma semelhança: indivíduo ou povo, habitava o espaço além da cristandade/civilização.

O indivíduo selvagem é ao mesmo tempo uma projeção: o homem liberto do controle social. Tanto quanto os habitantes da imaginada Índia (Le Goff, 1980), ele expressa ansiedades relativas à ordem social cristã: sexo (família); sustento (instituições políticas e econômicas) ; salvação (I greja). Ele não sofre restrições; é, de um lado, a encarnação do desejo e, de outro, a negação da razão.

O utra fonte para a compreensão da idéia de "homem selvagem" na Europa medieval éo "cavalei ro selvagem". N esse personagem se fundem homens reais e categorias imaginadas.

O selvagem medieval não era apenas um homem estranho aprisionado na cripta da mudez e da idiotice ou pregado na cruz de uma estrutura imutável; ele aparecia também como o protagonista efêmero da história ... Guibert de N ogent ... relata como os exércitos da primei ra Cruzada eram acompanhados por uma tropa de mendigos profissionais canibais, descal ços e sem armas ... organizados por um nobre normando como carregadores de provisões ... e do pesado equipamento usado para sitiar o inimigo ... Esses cruzados selvagens eram também parte da gesta D ei na tentativa de reconquistar os lugares sagrados em nome do cristianismo. 0 canibalismo não era desconhecido na Europa, pois o consumo de carne humana ocorria em al gumas partes da Inglaterra, França e Alemanha, especial mente em épocas de fome; durante os séculos nono e décimo bandos de assassinos vagabundos atacavam viajantes em áreas remotas, cortavam-nos e vendiam sua carne nos mercados como "carneiros de duas pernas". ${ }^{57}$

H avia, pois, cavaleiros selvagens "históricos", e deve ter sido muito problemática sua inclusão na gesta D ei e no encontro com o Anticristo. M as ha- 
via também o caval eiro selvagem romântico, vitimado pela paixão: Amadis, Lancelote, Tristão e tantos outros. Caído numa espécie de loucura selvagem, vivia isolado, nu, comendo carne crua. A loucura do cavaleiro selvagem tem por causa a paixão que faz perder a razão, atributo da humanidade plena; a paixão é selvagem. 0 amor cristão transformado em paixão carnal conduz à selvageria.

A paixão, convém lembrar, foi o terror de teólogos e moralistas tanto do Medievo quanto do Antigo Regime. Na mesma medida em quea teologia afirmava o que Flandrin (1976) chamou de "família monárquica", para fazer aceitar a obediência absoluta a um deus único e a um rei, ela condenava o amorpaixão, mesmo entre marido e mulher. Tomando por base a Epístola aos Efésios do apóstolo Paulo e as considerações de são Jerônimo, o amor concupiscente entre cônjuges era visto como equival ente ao adultério:

Desde a Antigüidade os teólogos o condenavam com vigor. "Adúltero é também 0 amante por demais ardente de sua esposa”, escrevera S. Jerônimo ... "O homem sábio deve amar sua esposa com discernimento, não com paixão. Que ele domine a paixão da voluptuosidade e não se deixe levar com precipitação ao acoplamento..." Essa atitude inspirada no estoicismo e mais genericamente na sabedoria antiga foi constantemente aquela dos teólogos medievais... ${ }^{58}$

O cavaleiro selvagem lendário era, pois, aquele que sucumbindo à paixão - oposta ao amor cortês - perdia a razão, central à idéia de civilização, caindo na loucura, característica do selvagem. De certa forma, representava uma Queda individual, alegoria da história humana quando o homem se afasta da trilha providencial.

A análise feita por Le Goff \& Vidal-Naquet (1979) a propósito do Yvain ou le Chevalier au lion, de Chrétien de Troyes, érica em significados. Yvain obtém de sua esposa Laudine licença para deixá-la por um ano, em busca de aventura. Se, após decorrido um ano ele não retornasse, perderia o amor da esposa.

Apaixonando-se por outra mulher e perdendo o prazo, Yvain enlouquece, rasga suas rou pas e, nu, penetra na floresta, isto é, num espaço selvagem. Rouba de um rapaz um arco e flechas, com os quais mata animais silvestres e os come crus. Em certo momento encontra um eremita que lhe dá pão eágua. Todos os dias, Yvain traz para o eremita alguma besta selvagem que caçou. Essa troca dura até que uma dama cura Yvain de sua loucura. Como dizem Le Goff \& Vidal-Naquet: 
Por menos familiarizado que se seja com a literatura da I dade M édia latina, reconhece-se facilmente na loucura de Yvain um topos cujos exemplos são numerosos, aquele do homem selvagem. 0 protótipo é um episódio célebre da Vita M erlini de Geoffroy de M onmouth, texto ele mesmo derivado de antigas tradições celtas. Responsável por uma batal ha que provoca a morte de seus dois irmãos, M erlin se torna um homem das florestas (fit silvester homo) ... O tema é freqüente no romance cortês e ganha destaque no O rlando furioso de Ariosto. ${ }^{59}$

Os autores evitam explicações psicologizantes e preferem uma interpretação estrutural: Yvain abandona tanto a aparência como o território dos nobres, ao qual se resumia o universo social da humanidade. Atravessa os campos cultivados e vai para mais além dos limites do espaço habitado.

A floresta será o lugar de sua loucura. Floresta mais complexa do que poderia parecer à primeira vista. Ela éo equival ente ao que representa no O riente o deserto, lugar de refúgio, da caça, da aventura, horizonte opaco do mundo das cidades, das vilas, dos campos. Mas ... na Bretanha ela é ainda mais: é o lugar onde se rompem as mal has da hierarquia feudal ... N essa floresta Yvain não mais será cavaleiro, mas um caçador-predador. ${ }^{60}$

Yvain, cavaleiro nobre, na floresta arma-se com arco e flechas roubadas de um rapaz da mais baixa condição social. 0 arco é a arma do caçador que se opõe à arma do cavaleiro dos torneios. E os autores descobrem uma interessante analogia com a figura do selvagem no pensamento grego.

H ouve um tempo, muito antes do século XII, quetambém conheceu uma oposição entre o guerreiro equipado e o arqueiro isolado, selvagem. Tal foi o caso da Grécia arcaica e clássica. Assim, o rei de Argos, numa peça de Eurípides, desqualifica, em nome das virtudes do hoplita, 0 arqueiro H eraclés “homem de nada que adquiriu uma aparência de bravura em seus combates contra as bestas e foi incapaz de qualquer outra proeza. Ele jamais portou um escudo em seu braço esquerdo nem enfrentou uma lança: portando o arco, a arma mais covarde, ele estava sempre pronto para fugir. Para um guerreiro, a prova da bravura não está no tiro do arco; ela consiste em manter seu posto e, sem baixar nem desviar o olhar, ver acorrer diante desi todo um campo de lanças erguidas, semprefirmeem seu posto". De Homero até o fim do século V o arco é a arma dos bastardos, dos traidores ... dos estrangeiros (como os citas em Atenas) . ${ }^{61}$ 
Os citas, lembro, eram o povo selvagem por excelência do imaginário grego. Segundo um mito helênico, teriam se originado pelo intercurso sexual de Heraclés com um ser híbrido, meio mulher meio serpente. Os citas eram tidos como nômades, habitantes do deserto e arqueiros. Em Heródoto, se Heraclés é herói civilizador, étambém um selvagem errante, tal como o foi 0 cavaleiro selvagem do M edievo, caçador solitário que se opunha ao caval ei ro "pesado", com sua armadura.

O arco é o símbolo da queda. "O que é legítimo na floresta, em face das bestas selvagens ... éa arma desleal num contexto de cavalaria". ${ }^{2}$ É a arma dos garçons sauvages, saídos do mundo marginal e que praticam "as formas inferiores da atividade militar".

Os romans de cour não só assimilam o arqueiro ao selvagem, mas o identificam com o signo de Sagitário, representado como um centauro, uma das metáforas antigas da selvageria.

No Conte du Graal, também deChrétien de Troyes, Perceval perde a memória a ponto de não mais se lembrar de D eus. No Li Estoire del Chevalier au Cisne, temos um homem ainda mais selvagem que Yvain, com o corpo coberto de pêlos como um animal.

Temos então um homem caído, errante, vivendo na floresta, nu e desgrenhado, caçador (predador) em contraste com o agricultor (produtor), que come carne crua. M uito semelhante ao cita do imaginário grego, e do ameríndio ainda a ser encontrado pelo imaginário europeu. A história de Yvain tem todas as características de um rito de passagem: um primeiro momento de condição civilizada; o ingresso na condição liminal de selvageria com a perda da razão, resultado da paixão por uma mulher outra que não sua esposa; a mediação do eremita (condição também ambígua); a salvação por uma mulher pura e o reingresso na civilização, na sociedade de corte. A história de Yvain poderia ser a história dos povos selvagens, saídos da trilha providencial cristã para serem redimidos e reintroduzidos na gesta Dei.

Além de indivíduos selvagens, existiriam também povos selvagens no limite da Europa civilizada, exemplificados pel os irlandeses, como nos mostra Leersen (1995).

Como já mencionado, um dos contrastes que marcaram o pensamento medieval era dado pela oposição entre, de um lado, o cultivado e construído - civilizado, cristão, abençoado - , e, de outro, o natural (wild, em língua inglesa), como a floresta e o oceano. Tal percepção expressava também a opo- 
sição entre humano e não-humano como analogia do contraste entre membro da sociedade e externo à sociedade. É pela desnaturalização do comportamento que os humanos ocupam uma posição superior na Grande Cadeia do Ser (Leersen, 1995).

De um lado, a oposição entre cristão e pagão expressava a oposição entre civilizado e selvagem; de outro, Leersen ressalta que o núcleo da civilidade medieval era a corte; civilização era, pois, também um conceito aristocrático. 0 comportamento cortês, estreitamente associado à noção de hierarquia, era a marca da civilidade, o que é coerente, por contraste, com a figura do cavaleiro selvagem.

Leersen nota ainda que fora do espaço civilizado localizava-se o que na França era chamado o vilein, o vil. Na Alemanha era o camponês, tratado com extrema depreciação pela literatura, como nas sátiras de Von Reuenthal, o que veio a se constituir num dos componentes das várias revoltas camponesas. Vilein era aquel eque vivia no campo, perigosamente próximo à natureza (embora coubesse a ele o cultivo da terra). À construção ideológica correspondia a relação social: semelhante a animais, deveria ser como tal tratado; sendo naturalmente inferior, devia ser disciplinado pela autoridade. É uma atitude que lembra Aristóteles, o filósofo que mais influenciou o pensamento erudito nos últimos séculos do medievo.

Alguns seres, com efeito, desde a hora de seu nascimento são marcados para ser mandados ou para mandar ... sempre se verá al guém que manda e al guém que obedece, e esta peculiaridade dos seres vivos se acha presente neles como uma decorrência da natureza em seu todo ... Entre os sexos também, o macho é por natureza superior e a fêmea inferior ... o mesmo princípio se aplica necessariamente a todo o gênero humano; portanto, todos os homens que diferem entre si para pior no mesmo grau em que a alma difere do corpo e o ser humano difere de um animal inferior ... são naturalmente escravos e para eles é melhor ser sujeitos à autoridade de um senhor, tanto quanto o é para os seres já mencionados. ${ }^{63}$

0 argumento de Aristóteles é complexo, mas para o que aqui interessa, os bárbaros, selvagens ou não, seriam naturalmente destinados à subordinação. No contexto cristão, a inferioridade natural do selvagem é inserida na concepção da Grande Cadeia do Ser.

A sociedade feudal espelha, em sua hierarquia vertical, a Grande Cadeia do Ser, com o princípio governante no topo como fonte da civilidade de onde ema- 
na a redenção da bestialidade, e no fundo da sociedade um enxame de subumanos incultos dirigidos pela paixão. ${ }^{64}$

Esse "fundo da sociedade" é o mundo dosirracionais e a paixão, como foi visto, é o grande inimigo da moralidade medieval. Se no "fundo da sociedade" estavam os camponeses, fora dela estava o H omo Sylvestris, negação da sociedade cristã e escravo da natureza, incapaz de controlar suas paixões e incapaz de vida sedentária. Semelhante a ele seria o irlandês.

0 irlandês selvagem ocupa um lugar tanto no tempo como no espaço. Com as Cruzadas o O cidente latino encontra o M editerrâneo oriental e uma filosofia da história de caráter geográfico que buscava explicar a marcha da civilização. Tal filosofia, como aponta Glacken, ${ }^{65}$ era a deuma história do mundo fundada em textos bíblicos e fontes clássicas que partia do princípio da maior antigüidade das terras orientais - ex oriente lux. Ao longo da história a civilização teria se deslocado gradativamente de leste para oeste, dirigida pela mão da Providência. Essa concepção, também encontrada no pensamento islâmico, partilhava a noção apocalíptica geral do medievo dando-Ihe uma dimensão espacial, ou geográfica: a humanidade encontraria seu fim quando o movimento alcançasse os limites extremos do O cidente. No século IV Severiano de Gabala afirmara que D eus havia localizado o Éden no leste para que o homem compreendesse que tal como a luz do céu se move para o oeste, assim também a raça humana corre em direção à sua morte.

Já no século III Pompeius Justinos vira a progressão da civilização desde a Pérsia e Assíria até a M acedônia e Roma, como parte de um translatio imperii, em que cada império decadente transmitia o poder para seu sucessor. Essa mesma percepção foi também a de são Jerônimo, Orosius e Otto de Freising. Este último, em As duas Cidades, lembrava finalisticamente que "agora todos vêem para que veio o I mpério Romano - aquele império que, dada a sua preeminência, era considerado eterno pelos pagãos e era considerado mesmo por nós como quase divino". ${ }^{66} \mathrm{O}$ fluxo na direção do O este era também expresso no progresso da religião, como mostrava o florescimento da vida monástica que havia principiado no Egito e agora tinha seu auge nas regiões da Gália e da Germânia.

Nesse contexto geográfico-apocalíptico, que é também uma percepção cíclica da história, Giraldus Cambrensis contrasta o Leste doentio com o O este saudável. Caracteristicamente, ele organiza o mundo numa escala hierárquica, desde a natureza inorgânica, as plantas e os animais, até o homem e os anjos. Deus transcende todos os seres criados. Mas há também como que uma 
hierarquia geográfica, onde a I rlanda ocupa o topo: pastagens verdejantes para o gado durante 0 ano todo, ar saudável sem "vapores pestilentos". M as parece ser uma hierarquia com tempos marcados: à medida que o mundo enveIhece ele cai na decrepitude; aproximando-se do fim tudo se corrompe é deteriorado. A I rlanda, ao tempo de Cambrensis, estaria ainda a salvo de tal destino.

No leste, o contato com a terra e a água traz a morte, em contraste com a I rlanda. As partes ocidentais do mundo, ainda que menos férteis têm o ar mais saudável e seu povo é mais robusto, embora menos agudo de espírito. No O riente, Baco e Ceres; no Ocidente, M arte e Mercúrio.

Sua teoria geográfica é parte de uma teoria mais geral das idades do homem. Assim, a Irlanda, de natureza mais jovem e pura, é habitada por um povo rude e selvagem. A I rlanda é como que a última etapa da humanidade, pois está no limite do mundo; era a última possibilidade de translatio imperii. Quem eram os irlandeses que ocupavam essa eschatiá medieval?

Para a Inglaterra, o irlandês era o wild man exemplar. Nas próprias palavras de Giraldus Cambrensis, em sua Topographia H ibernica, de 1170,

Esse é um povo silvestre, inospitaleiro; um povo que vive de bestas e que é como bestas; um povo que ainda adere à forma mais primitiva de vida pastoril. Pois, enquanto a humanidade no curso comum das coisas progrediu das florestas para os campos arados e para a vida em povoados e para a sociedade civil, esse povo épor demais preguiçoso para a agricultura e negligente quanto ao conforto material; e positivamente contrário às regras e legalidades do intercurso social; assim, tem sido incapaz e relutante a abandonar sua vida tradicional de florestas e pastagens. ${ }^{67}$

\section{Diz ainda Cambrensis que}

este povo habita um país tão remoto do resto do mundo, localizado em sua extremidade mais distante formando, por assim dizer, um outro mundo, isolado das nações civilizadas. Nada aprendem e nada praticam além do barbarismo no qual nasceram ... e que é para eles uma segunda natureza. Sejam quais forem os dons naturais que possuam, no que diz respeito à industriosidade eles são inúteis ${ }^{68}$

Em sua indolência, amam apenas a liberdade de não trabal har, como que recusando a condição humana imposta pela Queda. Localizados no extremo do mundo, não são capazes de utilizar o ambiente natural tão saudável. São, talvez, excessivamente jovens num meio natural jovem. Em resumo, são “wild 
men", como atestam seus cabelos longos e desgrenhados e suas roupas. Localizados no limiar do mundo, tanto quanto os citas selvagens do imaginário grego - "o mais jovem dos povos", ${ }^{69}$ para Heródoto - estavam, poder-se-ia dizer, como que à espera da chegada de uma civilização vinda do leste (agora a Inglaterra) em sua caminhada para o oeste - talvez para o fim dos espaços/fim dos tempos.

Em 1401 os selvagens irlandeses se tornam os H ibernicus et inimicus noster. O significado de tal representação era dado, entre outras coisas, por uma política de segregação que opunha ao "súdito britânico" o "fora-da-lei irlandês". Lembro que "fora da lei" poderia significar fora da humanidade plena. Significativamente, a Irlanda foi dividida em duas regiões: within the Palee beyond the Pale, dentro efora da civilidade.

Leersen observa ainda que Giraldus não se limitava a descrever (pejorativamente) os irlandeses; acrescentava às suas narrativas descrições fantásticas de mulheres barbadas e peixes com dentes de ouro, por exemplo, seguindo o exemplo de Plínio. A gens sylvestris de Giraldus era percebida, tanto quanto o seria depois o ameríndio, como a negação do progresso, mesmo porque o progresso só se explicava pela gesta Dei.

O discurso de Giraldus sobre as estranhas maravilhas da I rlanda é uma iconografia recebida padronizada, que nas descrições medievais atribui valor ao exotismo ... a selvageria da I rlanda [é] expressa pela iconografia de fenômenos naturais maravilhosos ... um eco direto daquela imaginação geográfica que une dois aspectos da noção de terras estranhas, significando tanto "estrangeiras" como "sobrenaturais". Aquela imaginação usa os espaços em branco do mapa para escrever ... hic sunt leones, ou preenche regiões distantes com raças plinianas como povos sem cabeça e com a face no tórax, povos que andam pulando sobre um único e grande pé, ou povos com caudas (homines caudati)

A I rlanda era o limite exterior do mundo ocidental ... A imagem da estranheza da I rlanda era corrente por toda a Europa ocidental ... a I rlanda estava na beira do oceano do mundo ...

E então, Colombo velejou para o outro lado. ${ }^{70}$

A Europa medieval não apenas se revelava incapaz de lidar com a alteridade remota, mas pouco interesse demonstrava pelo Outro, o não-cristão, o não-civilizado quelhe era geograficamente próximo. 
Vários fatores merecem ser considerados.

Como foi visto, não deixava de existir conhecimento geográfico e etnográfico. No entanto, o conhecimento permaneceu contido no que Hodgen chama de "bolsões de saber", relativamente isolados uns dos outros. Por isso mesmo, certas descobertas geográficas, como o caráter interior do mar Cáspio, feita por Rubruck em 1253, só foram incorporadas ao conhecimento europeu cinqüenta anos depois. Em vez de realidades geográficas, os cartógrafos continuavam preferindo decorar seus mapas com monstros humanos, como os monoculi ou anthropophagi, raças sem cabeça e assim por diante. M esmo os mapas relativos à Europa mantinham anacronismos flagrantes, como o de Hereford, que repetia os erros feitos por Orosius oitocentos anos antes (Hodgen, 1964).

Todavia, é preciso considerar que, além do isolamento ressaltado por Hodgen, havia outro "isolamento" em operação: aqueles "bolsões" eram em larga medida monastérios e, como já foi dito, a atitude dominante era contrária à experiência e ao novo; predominava a "recapitulação pia".

O isolamento geográfico não era, de fato, tão grande como se poderia supor, como mostra a própria Hodgen. Afinal, desde a Primeira I dade do Ferro, feiras periódicas estimulavam o contato por meio de mercadores itinerantes; desde a Segunda I dade do Ferro, instrumentos do M editerrâneo eram levados para os bárbaros ao norte dos Al pes por mercadores protegidos pelas tribos interessadas. Os gregos já conheciam a China e a Espanha; no século VII navios bizantinos al cançavam a Inglaterra; M arselha se comunicava com a África e com o Levante. 0 movimento missionário também se realizava desde cedo. A partir de Edessa, na M esopotâmia, o cristianismo foi levado à Pérsia e ao Hindustan entre os anos 150 e 180; no século IV alcançou os famosos citas de Heródoto, assim como a Abissínia, as ilhas Britânicas e os sudaneses. U ma missão foi enviada da Síria para Malabar, na Índia. No século V o cristianismo nestoriano al cançou a China e no século seguinte chegou à Índia, como atestado por Gregório de Tours em sua investigação sobre santo Tomás.

No entanto, por ocasião da Primeira Cruzada no século XI, pouco se sabia sobre os sarracenos, percebid os apenas como demônios pagãos. Nas Chansons de Geste eram retratados como monstros gigantescos, demônios com chifres, canibais, tão cruéis e desprovidos de moralidade a ponto de venderem suas esposas.

A teologia, já como discurso político, não fazia distinções entre os infiéis ou pagãos. Muçulmanos, persas, saxões, citas e outros eram todos agrupados sob o mesmo rótulo: pagãos selvagens. Porém, como foi visto, a noção de sel- 
vagem era parte de um conjunto de categorias utilizadas para legitimar valores como civilização, sanidade e ortodoxia. Selvageria poderia ser "traduzida" para insanidade ou heresia, na mesma medida em que civilização poderia ser traduzida em razão e cristandade. Tais noções

não se referem tanto a uma coisa, lugar ou condição específicos, quanto ditam uma atitude particular que comanda uma relação entre uma realidade vivida e al guma área problemática da existência que não pode ser conciliada facilmente com as concepções convencionais do normal ou familiar. ${ }^{71}$

A alteridade radical podia, então, ser assimilada à loucura tanto quanto à heresia. Bárbaros selvagens podiam ser agrupados sob as categorias ferus, ou sylvester, ou immanis (gigantes) ou insanus. Assim, santo Agostinho, na Cidade de D eus e nas Confissões, em sua percepção escatológica da história e da humanidade, opõe o insano, mal dito e herético, ao puro e eleito; o pecado à graça. Para ele, estabel ecer o sentido de sua própria vida era negar sentido a qualquer coisa radicalmente diferente dela, salvo como antítipo ou exemplo negativo.

A secular guerra contra os sarracenos fazia que as tribos estranhas fossem indiferenciadas, inibindo qualquer interesse comparativo. $\mathrm{N}$ ão-cristãos existiam apenas para ser eliminados ou convertidos. Ao mesmo tempo, como foi visto, Heródoto, Estrabão, Ptolomeu e outros tendiam a ser esquecidos, em benefício de Plínio, M ela ou Solinus. Como disse Francis Bacon, apenas lixo inútil continuava flutuando ao longo do curso do tempo.

Enquanto vicejavam as descrições fantásticas e/ ou estereotipadas do Outro, a Europa vivia séculos de lutas, desde a chegada dos bárbaros do N orte ao mundo romanizado até o avanço dos muçulmanos etártaros. 0 Anticristo se fazia presente e a sucessão de ameaças contra o cristianismo pode ter re forçado uma percepção teratológica e demonológica das alteridades. De um lado, o paganismo clássico e suas tradições orais preocupavam os Pais da I greja; de outro, as novas tribos bárbaras/selvagens que chegavam ameaçavam o cristianismo, justamente quando a I greja tentava se expandir. N ote-se que a conversão dos pagãos europeus foi muito lenta, estendendo-se do século $\mathrm{V}$ ao XVI.

Por que o Ocidente ignorou a realidade do oceano Índico, apesar dos missionários, dos mercadores e de M arco Polo? A pesar das viagens, ele permaneceu fechado aos ocidentais, sob controle de árabes, chineses eindianos. A rota efetivamente trafegada era terrestre, a rota mongol. M as havia outro 
bloqueio, aquele ao qual me referi a propósito dos "bolsões de saber": o medo de desvendar o desconhecido, as realidades geográficas que poderiam conflitar com verdades religiosas - a imagem do mundo era talvez mais uma questão teológica que geográfica. Abrir o oceano Índico era afrontar a imagem do mundo cristalizada no Orbis Terrarum, o que só foi feito com as navegações portuguesas e com a percepção da existência de um continente americano, mais do que a simples chegada às ilhas do Caribe, ainda consideradas como a Índia.

A concepção providencialista da história segundo uma teoria da humanidade que possuía apenas uma linguagem teológica dificilmente poderia lidar com a alteridade radical, a não ser em termos escatológicos. 0 selvagem Ihe servia como caso exemplar de uma condição humana (subumana?) resultante da Q ueda e da perda da graça e da razão. O u como motivo de evangelização, de redenção.

Porém, o mundo era explicado por uma causalidade transcendente dada, não por princípios físicos, mas metafísicos, concepção que só iria se modificar mais tarde com a hegemonia de uma percepção mecânica do cosmos e quantitativa do tempo.

num universo que se julgava ordenado, nas suas relações essenciais, mais por normas morais que por forças causais físicas imanentes, como se poderiam explicar as diferenças radicais entre os homens, a não ser pela suposição de que o diferente era, em certo sentido, inferior ao que passava por normal, vale dizer, as características do grupo no qual ocorria a percepção da diferença? ${ }^{72}$

Hodgen, como foi visto, explica a inexistência de uma etnografia "realista" na I dade M édia ressaltando fatores como isolamento e guerras, por exemplo. A meu ver, contudo, a explicação não está em fatores empírico-sociológicos, mas sim no plano metafísico: na concepção medieval da história; no caminho trilhado pelo homem na gesta Dei, isto é, numa concepção escatológica da humanidadeque cria (recria) tanto selvagens como raças monstruosas.

A concepção de uma humanidade única e de uma única trilha histórica, tanto quanto de um mundo organizado na Grande Cadeia do Ser, não abria espaço para o particular ou para a alteridade. Ao mesmo tempo, abria espaço para a exotização que imagina o selvagem, no limiar do espaço e da gesta Dei, no horizonte da história.

Contudo, é preciso considerar outro aspecto na relação entre o selvagem e a história. Existiam diferentes concepções de selvagem no M edievo, e desta- 
quei aqui o povo selvagem e o indivíduo selvagem, em larga medida com características atribuídas semel hantes. M as, ao longo do tempo, o estado selvagem ontológico da tradição hebraica foi sendo transformado em estágio. Abriuse caminho, então, junto com a passagem de um tempo qualitativo para outro, quantitativo, e da transcendência para a imanência, para que o selvagem fosse deslocado do espaço para o tempo: gradativamente, ele se tornou o primitivo.

Além disso, a dificuldade teológica de conceber uma humanidade selvagem terminou, em parte, conduzindo o imaginário a pensá-la menos como espiritualmente degradada que desprovida de razão; o selvagem pecava sem o saber. Ele possuía a inocência que explicava sua liberdade diante das regras da sociedade. Com isso surge uma imagem alternativa do selvagem, construído, em certo sentido, como o selvagem "rousseauniano". A partir do século $\mathrm{XV}$, quando as concepções morais medievais e o pensamento teológico são alcançados pel o humanismo emergente, o selvagem já começa a se transformar de motivo de medo e abjeção em motivo de inveja ou em instrumento de crítica social: como mostrou Le Goff (1980), o selvagem se torna alegoria da burguesia.

Se no pensamento teológico medieval não havia espaço para o conhecimento novo, pois era inibida a turpis curiositas, mas apenas para recapitulações; se a curiosidade crítica era herética, a ditadura teológica inibia o pensamento inovador e Plínio, Solinus e outros reinavam incontestes, reforçando as fantasias com a aceitação sem dúvidas da autoridade. Estimular a dúvida quanto à geografia ou quanto à etnografia maravilhosa poderia resultar em estimular a dúvida quanto à verdade das Escrituras.

Assim, as enciclopédias medievais eram repletas de fantasias e de seres teratológi cos. É o caso das mencionadas Etymologiae de I sidoro de Sevilha, autor retomado e acrescido de novas maravilhas, ao lado de descrições real istas, no D e U niverso, a enciclopédia carolíngia de M aur. No século XV, o Imago M undi de Pierre D'Ailly reedita as maravilhas imaginadas sobre a Índia.

Foi só com o descentramento trazido pelo copernicismo, pelas Grandes Navegações, pela descoberta de um N ovo Mundo habitado e habitável, assim como pela ruptura do cristianismo com a Reforma, pluralizando a idéia de religião dentro mesmo do cristianismo, que começou a se tornar possível o distanciamento necessário para uma etnografia e uma historiografia capazes de lidar com o Outro em sua particularidade.

Na geografia medieval, como foi visto, além da I rlanda estava o nada, o $\mathrm{M}$ ar $\mathrm{O}$ ceano. Limite do mundo, a I rlanda era habitada por selvagens. M as, como disse Leersen (1995), “E então, Colombo velejou para o outro lado". O u- 
tros selvagens foram encontrados e esse encontro teve uma conseqüência histórica para o selvagem europeu, do qual o irlandês é um caso exemplar, mas não único.

Com o descobrimento do Novo Mundo, a Irlanda deixa de ser a U Itima Thule e perde o status de estar "à beira"; no plano imaginário, a descoberta da América torna a I rlanda próxima da Europa. Isso significa que o tipo medieval de exoticismo não pode mais prevalecer eque o status da Irlanda se transforma de "Ionge" para "perto", de "distante" para "doméstico". 73

O s irlandeses como que saíram da natureza para entrar na sociedade e na história. Já não eram seres semibestiais que viviam num meio selvático: "Ao invés de alienígenas de outro mundo, os irlandeses são agora súditos recalcitrantes do Rei...."74 Já no século XVII, Davies em A discoverie of the true causes why I reland was never entirely subdued argumenta em favor da integração da I rlanda na "Common Law" britânica, como forma de exorcizar aquela incômoda alteridade.

O pensamento medieval não era homogêneo e nele o selvagem ocupou vários registros. Podia representar a corrupção da espécie humana e localizar-se num degrau inferior da Grande Cadeia do Ser; nela, podia ser a solução para a continuidade entre a besta e o homem; podia expressar ansiedades e repressões; podia exprimir a vontade divina e até mesmo o fim dos tempos; podia exemplificar a segunda Queda, após o Dilúvio; podia representar a perda da graça. N esse contexto é significativa a observação de Thomas: "não é fortuito que o símbolo do Anticristo fosse a Besta, ou que o Diabo costumasse ser retratado como combinação de homem e animal". ${ }^{75}$ Retratado, pois, de maneira semelhante às "raças plinianas".

O selvagem podia ser estado ou estágio; podia ser demoníaco ou natural. Como criatura exemplar de Deus, podia ser a prova do poder divino não limitado a uma única Criação.

Qual o significado do selvagem?

O homem selvagem era um espelho para a história, na medida em que vivia fora dela, na natureza. Como diz Bartra, o selvagem permite refletir sobre o sentido da história. Por isso mesmo o selvagem como "homem natural", primitivo, continuou desempenhando o papel que Ihe cabia desde a An- 
tigüidade (e que continua ainda a desempenhar): a imagem invertida que torna possível pensar a civilização; o O utro radical.

Povo ou indivíduo, e as duas categorias tendiam a se fundir, o selvagem expressava a alteridade que só podia ser compreendida na idéia de história ou idéia do homem - se posta fora da história ou da humanidade. Ele expressa uma perplexidade. Porém,

Se não sabemos o que é a "civilização", sempre podemos encontrar um exemplo do que ela não é. Se não temos certeza do que é a sanidade, podemos ao menos identificar a loucura quando a vemos. Do mesmo modo, no passado, quando os homens não tinham certeza da qualidade exata do seu senso de humanidade, recorriam ao conceito de estado selvagem para designar uma área de subumanidade que se caracterizava por tudo que não fossem ${ }^{.76}$

Em outras palavras, é o que dizem Le Goff \& Vidal-Naquet:

Não éfácil definir com precisão o conjunto que podemos chamar de "homem selvagem" ... É com efeito pela via de suas representações do homem selvagem que ... as sociedades humanas têm definido suas relações com o outro. Não é em si mesmo que o homem selvagem concerne as sociedades históricas. Todo o jogo se passa nas relações que se estabelecem no nível das expressões escritas ou figuradas, como no nível das instituições, entre o homem "selvagem" e seu irmão "cultivado". Corte radical, reversibilidade, estabel ecimento de séries intermediárias, cada cultura tem seu modo de classificar os homens. De Enkidu, irmão selvagem do rei mesopotâmico de Uruk, Gilgamesh, a Tarzan e ao Yeti, passando pelo Ciclope e por Caliban, a literatura definiu simultaneamente uma concepção do homem em face dos deuses, das bestas, dos outros homens que classifica, exclui ou inclui segundo as épocas e segundo as pessoas. ${ }^{77}$

O selvagem intra-europeu, junto com a Índia e os povos ou indivíduos monstruosos herdados da Antigüidade, era até os D escobrimentos o "espeIho" que permitia a construção da civilidade, da civilização de corte, do cristianismo civilizatório e do progresso. 0 irlandês "exemplar" era, por isso, necessário ao pensamento europeu.

Dado o encontro com o ameríndio, o irlandês selvagem deixa de estar no limite do mundo, na beira do $\mathrm{M}$ ar O ceano. Ele como que se desloca para o interior do universo ordenado. Simbolicamente deslocado no espaço - um espaço que se expande enormemente - o selvagem intra-europeu se desloca 
também para dentro da história, que só existe com a domesticação, com a inclusão no domus e no cosmos, oposto ao caos. Na medida em que ele sai da natureza e entra na civilização, o ameríndio ocupa seu lugar, ea noção de selvagem passava a servir para "trabalhar" novos contextos de difícil resolução teológica.

Porém, se o encontro com o ameríndio retirou os irlandeses de sua eschatiá, isto não se deu de imediato: no século XVII eles eram ainda percebidos como homine caudatis canibais. Por sua vez, $M$ cGrane ${ }^{78}$ afirma que com a descoberta do Novo M undo terminava a era dos monstros. Pelo contrário, os seres monstruosos, junto com Satã, passaram a fixar residência no continente americano por muito tempo, fazendo que o Novo M undo se tornasse, de certa forma, velho.

Quando o suposto selvagem se tornava conhecido, a experiência não eliminava o conceito, mas o deslocava para mais adiante, para a fronteira do desconhecido, a fronteira entre o humano e o subumano; entre o histórico e o não histórico; entre o racional e o irracional. O selvagem sempre esteve associado a um lugar, o lugar não conhecido, o fim do mundo, expresso nos mapas pelas ilustrações de monstros. 0 selvagem existia em regiões selvagens, isto é, regiões ainda não domesticadas, ao mesmo tempo em que servia para domesticar o desconhecido.

A idéia de história formulada no M edievo não conseguia lidar com o particular e com o evento significativo em si mesmo. A conjunção de uma teoria transcendental da humanidade com a noção de uma Grande Cadei a do Ser criava sérios obstáculos para a apreciação do O utro em seus próprios termos. Porém, a recusa do novo impedia experienciar a alteridade. Foi armado com uma tal concepção da humanidade que boa parte do pensamento europeu iniciou seu encontro com o Novo Mundo.

Construído o selvagem no imaginário popular e no pensamento erudito, o encontro com o ameríndio, notadamente o canibal, foi ambíguo e muitas vezes assustador.

M as, seria esse novo selvagem tão abominável quanto aquele que praticava os rituais descritos por M inucius Felix ao final do século II A.D.?

Quanto à iniciação de novos membros, os detal hes são tão repulsivos quanto bem conhecidos. Uma criança, coberta com massa de pão para enganar o incauto, é colocada perante o noviço. Este o apunhala até a morte ... enganado pela 
cobertura ele pensa que seus golpes são inofensivos. Então - é horrível - eles bebem avidamente 0 sangue da criança e disputam enquanto dividem suas pernas. Através dessa vítima eles se mantêm unidos e o fato de partilharem o conhecimento do crime garante seu silêncio ... No dia da festa eles se reúnem com seus filhos, irmãs, mães, pessoas de ambos os sexos e de todas as idades. Quando todos estão abrasados pela festividade e a luxúria impura acesa pela embriaguez, pedaços de carne são jogados para um cão amarrado a uma lâmpada. 0 cão pula, para além do comprimento de sua corrente. A luz, que poderia ter sido testemunha traidora, se apaga. Agora, na escuridão tão favorável ao comportamento desavergonhado, eles tecem os liames de uma paixão inominável, ao sabor da sorte. E todos são incestuosos, se não de fato, pelo menos por cumplicidade, pois tudo que éfeito por um deles corresponde aos desejos de todos eles. ${ }^{79}$

O que M inucius Felix descrevia não era uma orgia dionisíaca; era a celebração da Eucaristia aos olhos de um pagão! Ainda por cima, os cristãos reverenciariam os órgãos genitais do sacerdote e a cabeça de um jumento, animal desprezível.

É uma ironia estranha e reveladora que os primeiros cristãos tivessem entrado na história - numa época deterríveis perseguições - com a imagem dehomens selvagens. Durante o império de M arcus Aurelius o povo e as autoridades percebiam as seitas cristãs como culpadas de infanticídio, canibalismo e incesto. ${ }^{80}$

$\mathrm{N}$ ão é de estranhar, pois, que tivessem sido atirados aos leões - afinal, era apenas um espetáculo de feras comendo feras. $\mathrm{N}$ ão muito diferente foi a reação - após um momento inicial de entusiástico proselitismo em face de ameríndios inocentes - de franciscanos e dominicanos confrontados com as supostas práticas satânicas dos nativos do M éxico.

E como teria sido o encontro entre cristãos e selvagens africanos na época dos D escobrimentos? Temos interessantes relatos na Carta de Antoniotto U sodimare e na N avegação Primeira de Luís de Cadamosto, ambas de 1455.

Usodimare, além de mercadorias, perseguia também o Reino de Preste João, já transferido para a África.

$N$ a verdade, pela terra firmefaltavam menos de CCC léguas até o país do Preste Jão, não digo até sua pessoa mas sim até onde começa o seu território; e se me tivesse podido demorar, teria visto o capitão do rei de M elli, o qual se encontrava a seis jornadas de nós com C homens, e com el estavam V cristãos do Preste João... 
O Imperador e o Patriarca cristão da Núbia e Etiópia, Preste João, chama-se Abet Selip, que significa "Cem homens". Estas regiões são as que ficaram ao Preste João depois que o Grão Khan do Cathay, de nome Castigan, Ihe deu batalha em 1187 na bela planície de Tenduch no Cathay. Esmagado pela inúmera multidão dos adversários, o Preste João perdeu todos os territórios que possuía na Ásia. Conservou somente as províncias da Etiópia e da Núbia, em que abunda o ouro e a prata. ${ }^{81}$

U sodimare relata ainda a existência de unicórnios, assim como de homens com cauda que comem seus filhos. Em busca do santo encontra o selvagem teratológico.

Cadamosto se autodefine como enviado de D. H enrique, santo, virgem, que combatia os inimigos da cristandade. Descreve os vários selvagens que encontra pelo caminho. Os das ilhas Canárias que andam nus e vivem em cavernas; com armas rudimentares matam-se entre si como feras. Com a cerimônia de posse de um novo Senhor, um deles se oferece para morrer por ele, atirando-se de um penhasco. Na povoação de Hodem encontra "M ahometanos, inimicíssimos dos Cristãos", sem habitação fixa e que vivem vagando pelo deserto. Descreve ainda homens mudos e outros que "têm nos lados da boca dous dentes grandes ... são de aspecto terrível, as gengivas vertem sangue como os beiços".

Em Gâmbia, entram em conflito com os selvagens locais.

então Ihes fizemos perguntar, por que causa nos ofendiam, sendo nós gente pacífica ... a sua resposta foi, que pelo passado tinham al guma notícia de nós ... tinham por certo que nós, os Cristãos, comíamos carne humana, e que não comprávamos os N egros senão para os comer. ${ }^{82}$

Se os cristãos eram canibais para o romano, não o eram menos para os africanos ameaçados de escravidão. Para o pagão, selvagem era o cristão.

NOTAS

${ }^{1}$ M ALIN OWSKI, B. A Vida Sexual dos Selvagens. Rio de Janeiro: Francisco Alves, 1983, p.498.

${ }^{2}$ WO ORTM AN N, K. O Selvagem na História. Heródoto ea questão do Outro. Revista de Antropologia/USP, São Paulo, v.43, n.1, p.13-59, 2000. 
${ }^{3}$ HARTOG, F. Le M iroir d'H érodote. Essai sur la répresentation de l'autre. Paris: Gallimard, 1980.

${ }^{4}$ WHITE, H. Trópicos do discurso: ensaios sobre a crítica da cultura. São Paulo: Edusp, 1994.

${ }^{5}$ BARTRA, R. Wild M en in the Looking Glass. The mythic origins of European 0 therness. Ann Arbor: The University of Michigan Press, 1994.

${ }^{6}$ GU SD ORF, G. Les O rigines des Sciences H umaines. Paris: Gallimard, 1967, p.54.

${ }^{7}$ COLLIN GWO O D, R. G. A I déia de História. Lisboa: Presença, 1994.

${ }^{8}$ Ibidem, p.71, grifo no original.

${ }^{9}$ H ARTO G, F. Entre les anciens et les modernes, les sauvages; ou, de Claude Lévi-Strauss à Claude Lévi-Strauss. Ghadiva (Révue d'histoire et d'archives de l'anthropologie), v.11, p.23-30, 1992.

${ }^{10}$ CASSI RER, E. The Individual and the Cosmos in Renaissance Philosophy. Philadelphia: University of Pennsylvania Press, 1972; ELIAS, N . Involvement and Detachment. N ew York: Basil Blackwell, 1987; . A Sociedade dos Indivíduos. Rio de Janeiro: JorgeZahar, 1994.

${ }^{11}$ BERLIN , I. Vico e H erder. Brasília: Ed. UnB,1976.

${ }^{12}$ ARIĖS, Ph. $O$ Tempo da História. Rio de Janeiro: Francisco Alves, 1989, p.103, grifos meus.

${ }^{13}$ DU M ONT, L. O Individualismo: uma perspectiva antropológica da ideologia moderna. Rio de Janeiro: Rocco, 1985.

${ }^{14}$ SOUZA, J. A., DE BONI, L. Introdução. In: OCKH AM , W. Brevilóquio sobre o principado tirânico. Petrópolis: Vozes, 1988, p.15, grifos meus.

${ }^{15}$ ELIAS, 1987; 1994.

${ }^{16}$ SOUZA \& DE BONI, 1988, op. cit., p.15-6, grifos meus.

${ }^{17}$ OCKHAM , G. de. Brevilóquio, capítulos 7, 8.

${ }^{18}$ WHITROW, G. J. 0 tempo na História. Rio de Janeiro: Jorge Zahar, 1993.

${ }^{19}$ M uito mais tarde, no século XV, um banquete ritual servido pel o duque de Gloucester, composto de quatro pratos, replicava simbolicamente aquelas quatro idades cósmicas: durante o primeiro prato, assistia-se à representação de um jovem, sobre uma nuvem (o elemento ar), no início da primavera, associada ao humor sangüíneo. Durante o segundo prato, ocorria a representação de um guerreiro em meio ao elemento fogo, associado ao verão e ao humor colérico. 0 terceiro prato era acompanhado pela representação de um homem com uma foice, em meio a um rio (outono, água, humor fleumático, colheita). 0 último prato era acompanhado pela representação do inverno por um homem velho, sentado nu- 
ma pedra fria e dura (o elemento terra e o humor melancólico). Como observou WHITROW (1993, p.91), "à medida que os convidados avançavam nesse pouco piedoso banquete... eram convidados a ver nele os quatro serviços do festim de sua própria vida".

${ }^{20}$ COLLIN GWOOD, R. G., 1994, op. cit., p.81.

${ }^{21}$ ARIÈS, 1989, op. cit., p.94.

${ }^{22}$ WHITROW, 1996, op. cit.

${ }^{23}$ SM ALLEY, B. Historians of the M iddleAges. London: Thames \& Hudson, 1974, p.30.

${ }^{24}$ GARAU DY, R. Faith and revolution. Ecumenical Review, v.25, p.60-71, 1973. p.66-7.

${ }^{25}$ ARIĖS, 1989, op. cit., p.132.

${ }^{26} \mathrm{Ibidem}, \mathrm{p} .127$.

${ }^{27}$ GUSD ORF, 1967, op. cit., p.188.

${ }^{28}$ BLOCH , M . Feudal Society. London: Routledge \& Kegan Paul, 1961.

${ }^{29}$ GLASSER, R. Timein French Lifeand Thought. M anchester: M anchester University Press, M anchester, 1972, p.17.

${ }^{30}$ ARIÈS, 1989, op. cit., p.99-100.

${ }^{31}$ GAOS, J. Historia de N uestra I dea del M undo. M éxico: Fondo de Cultura Económica, 1992, p.19, grifos do autor.

${ }^{32}$ Curiosamente, podemos ver que as imagens iconográficas se repetem sempre em múltiplos de 4 ou de 7, mas a investigação sobre o possível significado, talvez relacionado às idades do homem, escapa ao âmbito deste trabalho.

${ }^{33}$ GAOS, 1992, op. cit., p.22, grifo do autor.

${ }^{34}$ Ibidem, p.28, grifos meus.

${ }^{35}$ No século XVI há como que um recrudescimento do medo escatológico, com o milenarismo associado a uma demonologia, influenciando a Reforma de Lutero tanto quanto a Contra-Reforma, e contribuindo para moldar muitas representações do novo "selvagem" encontrado no continente americano, encontro esse que realimentaria o próprio medo. Ao tempo do Renascimento, se já surgia uma concepção de história nova, como aquela de M aquiavel, o milenarismo informava outras concepções, como a de Jean Bodin. Já no século XVII Vieira, defensor dos indígenas brasileiros, construía com base no joaquinismo sua utopia, na qual Portugal ocupava um lugar central.

${ }^{36}$ ARIÈS, 1989, op. cit., p.134. 
${ }^{37}$ H O D GEN, M . T. Early Anthropology in the Sixteenth and Seventeeth Centuries. Philadelphia: University of Pennsylvania Press, 1964.

${ }^{38}$ HERÓD OTO. História. Trad. M ário da Gama Kury. Brasília: Ed. UnB, 1988.

${ }^{39}$ HODGEN, 1964, op. cit., p.34.

${ }^{40}$ HOD GEN, 1964, op. cit., p.59.

${ }^{41}$ LE GOFF, J. Para um novo conceito de I dade M édia. Lisboa: Estampa, 1980.

${ }^{42}$ LE GOFF, J. The M edieval Imagination. Chicago: Chicago University Press, 1988.

${ }^{43}$ WHITE, 1994, op. cit., p.183.

${ }^{44}$ Ibidem, p.185.

${ }^{45}$ LE GOFF, J., 1980, op. cit., p.265.

${ }^{46}$ LE GOFF, 1980, op. cit., p. 276 .

${ }^{47}$ Ibidem, p.273.

${ }^{48}$ Ibidem, p.279.

${ }^{49}$ Ibidem, p.279-80.

${ }^{50}$ LEERSEN , J. Wildness, Wilderness and I reland: medieval and early-modern patterns in the demarcation of civility. Journal of the History of Ideas, Jan. 1995, p.25-39.

${ }^{51}$ BARTRA, 1994, op. cit.

${ }^{52} \mathrm{~A}$ propósito de mouros, considerados selvagens no M edievo, faço aqui uma curiosa observação relativa à Espanha atual, com base nas considerações de Juan Arazandi, antropólogo da UNED. Na primeira metade do século XX, os nacional istas bascos utilizavam o termo depreciativo maketos para designar os imigrantes pobres de outras regiões da Espanha. 0 maketo era o paradigma do Outro, aquel e que ameaçava a pureza de uma suposta "raza basca". Para os "puros pirenaicos" o termo já designava, desde o século XVI, não apenas os judeus e moros, mas também os outros espanhóis, suspeitos de terem sangue judeu ou mouro; de não serem cristianos viejos e de não terem limpieza de sangre. 0 termo continuou a existir no século XX. Porém, ainda hoje se usa o termo moro para designar os imigrantes marroquinos que tanto assustam os espanhóis; um termo que sai "das bocas de espanhóis cujos parentes foram quiçá estigmatizados há apenas uma ou duas gerações como maketos". A atual Ley de Extrangeria sugere que "a síndrome racista comum de nacionalistas bascos e nacional istas espanhóis não é, de modo algum, coisa do passado" (ARAZAN DI, J. “M aketos” y moros. El País, Madrid, 2.Ago.2000, p.11).

${ }^{53}$ BARTRA, 1994, op. cit., p.90, grifos no original. 
${ }^{54}$ I bidem, p.96, grifos meus.

${ }^{55}$ I bidem, p.116.

${ }^{56}$ WHITE, 1994, op. cit., p.187.

${ }^{57}$ BARTRA, 1994, op. cit., p.127, grifos meus.

${ }^{58}$ FLAN D RI N , J.-L. Familles: parenté, mai son, sexualité dans l'ancienne societé. Paris: H achette, 1976, p.157.

${ }^{59}$ LE GOFF, J., VIDAL-NAQUET, P. Lévi-Strauss en Brocéliande. In: BELLOUR, R., CLÉM ENT, C. (Org.) Claude Lévi-Strauss. Paris: Gallimard, 1979, p.269-70, grifos no original.

${ }^{60}$ I bidem, p.272-3.

${ }^{61}$ I bidem, p.274, grifos meus.

${ }^{62}$ I bidem, p.277.

${ }^{63}$ ARIST ÓTELES. Política. Trad. M ário da Gama Kury. Brasília: Ed. UnB, 1985, p.1254a, 1254b.

${ }^{64}$ LEERSEN, 1995, op. cit., p. 27.

${ }^{65}$ GLACKEN , C. J. Traces on the Rhodian Shore. Berkeley, Los Angeles, London: University of California Press, 1967.

${ }^{66}$ Apud GLACKEN , 1967, op. cit., p.278.

${ }^{67}$ Apud LEERSEN, 1995, op. cit., p.30.

${ }^{68}$ Apud GLACKEN, 1967, op. cit., p.281.

${ }^{69}$ HERÓDOTO, 1988, op. cit.

${ }^{70}$ LEERSEN, 1995, op. cit., p.32.

${ }^{71}$ WHITE, H., 1994, op. cit., p.170.

${ }^{72}$ I bidem, p.175.

${ }^{73}$ LEERSEN, 1995, op. cit., p.32.

${ }^{74}$ I bidem, p.33.

${ }^{75}$ TH OM AS, K. 0 homem eo mundo natural. São Paulo: Companhia das Letras, 1988, p.43.

${ }^{76}$ WHITE, 1994, op. cit., p.171.

${ }^{77}$ LE GOFF \& VIDAL-NAQUET, 1979, op. cit., p.287-8.

${ }^{78}$ M cGRANE, B. Beyond Anthropology. New York: Columbia University Press, 1989. 
Klaas Woortmann

${ }^{79}$ Apud BARTRA, R., 1994, op. cit., p.41.

${ }^{80}$ Ibidem, p.41.

${ }^{81}$ GODIN H O, V. M . D ocumentos sobrea Expansão Portuguesa. v.llI . Lisboa: Cosmos, 1956. p.99-100, p.102-3.

${ }^{82}$ Ibidem, p.173. 